\title{
CURRENT TRENDS IN THE DEVELOPMENT OF HEAT-RESISTANT COATINGS BASED ON IRON, NICKEL AND COBALT ALUMINIDES
}

\author{
N. B. Pugacheva \\ Institute of Engineering Science, Ural Branch of the Russian Academy of Sciences, 34 Komsomolskaya st., \\ Ekaterinburg, Russian Federation
}

Corresponding author. E-mail: nat@,imach.uran.ru ; address for correspondence: ul. Komsomolskaya 34, Ekaterinburg, Russian Federation. Tel.:375-35-91; fax: 374-53-30.

Long-term research results on the structural condition of heat-resistant coatings based on iron, nickel and cobalt aluminides applied to gas turbine blades by diffusion methods or spraying, as well as on their degradation and damageability under operational conditions, are presented. Peculiarities of the formation of these coatings and possible types of their defects are analyzed. Results of studying the protective properties of multilayer coatings with different chemical and phase structures are given.

Keywords: gas turbine, high-temperature strength, heat resistance, coatings, aluminides, oxide film, diffusion, spraying, cracks.

DOI: $10.17804 / 2410-9908.2015 .3 .051-082$

\section{References}

1. Abraimov N.V., Yeliseyev Yu.S. Khimiko-termicheskaya obrabotka zharoprochnykh stalei $i$ splavov [Chemical heat treatment of heat-resistant steels and alloys]. Moscow, Intermet Engineering Publ., 2001, 622 p. (In Russian).

2. Goward G.W. Progress in coatings for gas turbine airfoils, 1998, no. 108, 109, pp. 73-79.

3. Guzanov B.N., Kositsyn S.V., Pugacheva N.B. Uprochnyayushchie zashchitnye pokrytiya $v$ mashinostroenii [Strengthening Protective Coatings in Mechanical Engineering]. Ekaterinburg, UrO RAN Publ., 2004, 244 p. (In Russian).

4. Movchan B.A., Malashenko I.S. Zharostoikie pokrytiya, osazhdaemye $v$ vakuume [Heat-Resistant coatings Precipitated in Vacuum]. Kiev, Naukova Dumka Publ., 1983, 232 p. (In Russian).

5. Sychyov M.M. Neorganicheskie klei [Inorganic Glues]. Leningrad, Khimiya Publ., 1986, 152 p. (In Russian).

6. Kosolapova T.Ya. ed. Svoistva, poluchenie $i$ primenenie tugoplavkikh soedineniy: Spravochnik [Properties, Production and Application of Refractory Compounds: Reference book]. Moscow, Metallurgiya Publ., 1986, 928 p. (In Russian).

7. Kositsyn S.V., Vandysheva N.B., Guzanov B.N., et al. Effect of the composition and structure of heat-resistant nickel alloys on the structure and properties of diffusion coatings. Zashchitnye pokrytiya na metallakh, 1987, vol. 21, pp. 20-24. (In Russian).

8. Pugacheva N.B., Kositsyn S.V. Babich N.V. Thermal diffusion coatings based on ferroalloys with REM. Fizika i khimiya obrabotki materialov, 1998, no. 4, pp. 42-48. (In Russian).

9. Sorokin V.G., Guzanov B.N., Babynkin A.N., Vandysheva N.B., et al. Primenenie diffuzionnykh pokrytiy dlya zashchity vysokokhromistykh nikelevykh splavov ot vozdeistviya agressivnykh gazovykh sred. V kn.: Temperaturoustoichivye pokrytiya [Application of diffusive coatings for the protection of high-chromium nickel alloys against hostile gas environment. In: HeatResistant Coatings]. Leningrad, Nauka Publ., 1985, pp. 172-177. (In Russian).

10. Pugacheva N.B., Ekzemplyarova E.O., Zadvorkin S.M. Studying the structure and physical properties of Fe-Cr-Al alloys. Metaly, 2006, no. 1, pp. 68-75. (In Russian).

11. Borisenok G.V., Vasilyev L.A., Voroshnin L.G., et al. Khimiko-termicheskaya obrabotka 
metallov $i$ splavov. Spravochnik [Chemical and thermal treatment of metals and alloys. Reference book]. Moscow, Metallurgiya Publ., 1981, 424 p. (In Russian).

12. Kositsyn S.V., Litvinov V.S., Sorokin V.G., Gervasiev M.A. Effect of silicon on diffusion in nickel-aluminum alloys. Phizika metalov i metallovedenie, 1980, vol. 49, no. 5, pp. 1063-1067. (In Russian).

13. Smirnov Yu.G., Lebedeva M.A., Kositsyn S.V., et al. Studying the damageability of slip silipide-alumina coatings on aircraft GTE turbine blades under operation. Aviatsionnaya promyshlennost, 1988, no. 1, pp. 68-71. (In Russian).

14. Kositsyn S.V. Splavy i pokrytiya na osnove monoalyuminida nikelya [Alloys and Coatings Based on Nickel Monoaluminide]. Ekaterinburg, UrO RAN Publ., 2008, 278 p. (In Russian).

15. Muboyadzhan S.A., Lesnikov V.P., Kuznetsov V.P. Kompleksnye zashchitnye pokrytiya turbinnykh lopatok aviatsionnykh GTD [Complex Protective Coatings on Aircraft GTE Blades Turbine Blades]. Ekaterinburg, Kvist Publ., 2008, 208 p. (In Russian).

16. Pugacheva N.B. Mazayev E.S. Protective properties of high-temperature composite coatings. Phizika i khimiya obrabotki materialov, 2001, no. 4, pp. 82-90. (In Russian).

17. Vandysheva N.B., Fedorov P.A., Klyueva N.V., et al. Multicomponent strengthening coatings for high-temperature parts of powerful diesels. Zashchitnye pokrytiya na metallakh, 1990, iss. 24, pp. 100-104. (In Russian).

18. Padture N.P., Gell M., Jordan E.H. Thermal barrier coatings for gas-turbine engine applications, Science, 2002, vol. 296, pp. 280-284.

19. Chubarov D.A., Matveev P.V. New ceramic materials for thermal barrier coatings on GTE rotor blades. Aviatsionnye materialy i tekhnologii, 2013, no. 4, pp. 43-46. (In Russian).

20. Budinovsky S.A., Muboyadzhan S.A., Gayamov A.M., Matveev P.V. Development of ion plasma heat-resistant metal layers of thermal barrier coatings for cooled turbine rotor blades. Metallovedenie i termicheskaya obrabotka metallov, 2013, no. 12, pp. 16-21. (In Russian).

21. Schlichting K.W., Padture N.P., Jordan E.H., Gell M. Failure modes in plasma-sprayed thermal barrier coatings. Materials Science and Engineering, 2003, vol. A342, pp. 120-130.

22. Zhu D., Miller R.A. Thermal Conductivity and Sintering Behavior of Advanced Thermal Barrier Coatings. NASA. TM-2002-211481, 2002, 15 p.

23. Gayamov A.M., Budinovsky S.A., Muboyadzhan S.A., Kosmin A.A. Choosing a heatresistant coating for the VZhM4 high-temperature rhenium-ruthenium-containing nickel alloy. Trudy "VIAM", 2014, no. 1. (In Russian). URL: http://viamworks.ru/plugins/content/journal/uploads/articles/pdf/639.pdf. (accessed 31.05.2015). 
Подана в журнал: 21.05 .2015

УДК 621.793.6:621.762

DOI: $10.17804 / 2410-9908.2015 .3 .051-082$

\title{
СОВРЕМЕННЫЕ ТЕНДЕНЦИИ РАЗВИТИЯ ЖАРОСТОЙКИХ ПОКРЫТИЙ НА ОС- НОВЕ АЛЮМИНИДОВ ЖЕЛЕЗА, НИКЕЛЯ И КОБАЛЬТА
}

\author{
Н. Б. Пугачева
}

\begin{abstract}
Федеральное государственное бюджетное учреждение науки Институт машиноведения Уральского отделения Российской академии наук, ул. Комсомольская, 34, Екатеринбург, Российская Федерация Ответственный автор. Электронная почта: nat@imach.uran.ru; адрес для переписки: ул. Комсомольская, 34, Екатеринбург, Российская Федерация. Телефон: 375-35-91; факс: 374-53-30
\end{abstract}

Представлены результаты многолетних исследований структурного состояния жаростойких покрытий на основе алюминидов железа, никеля и кобальта, наносимых на лопатки газовых турбин диффузионными методами и напылением, а также их деградации и повреждаемости в эксплуатационных условиях. Проанализированы особенности формирования и возможные виды дефектов этих покрытий. Приведены результаты исследований защитных свойств многослойных покрытий разного химического и фазового составов.

Ключевые слова: газовая турбина, жаропрочность, жаростойкость, покрытия, алюминиды, окисная пленка, диффузия, напыление, трещцины.

\section{1. Введение}

Ведущими направлениями развития энергетики являются теоретические и экспериментальные исследования физико-химических процессов, определяющих облик энерготехнологических комплексов нового поколения на базе газотурбинных и парогазовых установок, использующих в качестве исходного топлива уголь и другие различные виды топлива (газ, древесные отходы и др.); создание гибридных энергоустановок, включающих в себя высокотемпературные топливные элементы и газотурбинные установки (ГТУ); создание новых типов экологически чистых, энергоэффективных источников тепловой и электрической энергии, в том числе на основе электрохимических генераторов. Для решения этих задач важную роль играет уровень развития технологий получения жаропрочных сталей и сплавов, а также технологий нанесения на них жаростойких покрытий. Важнейшим системным вызовом, определяющим направления развития материалов для энергетики, является жесткая конкурентная борьба за сырьевые и топливные мировые ресурсы. Одним из основных требований в условиях санкций стран Запада против России становится мощное и стабильное развитие энергетического комплекса страны, в итоге во многом определяющее её уровень развития и роль в мировой экономике. Это во многом определяет направления развития научных фундаментальных и прикладных исследований, в том числе и в области материалов и покрытий энергетического назначения.

Многолетний опыт эксплуатации ГТУ и анализ поврежденности различных деталей, на примере лопаток, работающих в максимально жестких условиях [1-3], показывает, что процесс разрушения почти всегда начинается с поверхности. Это обусловлено изменениями состава, структуры и свойств поверхностных слоев материала под действием высоких температур и скоростного газового потока продуктов сгорания топлива. Стремление повышать кпд ГТУ привело к тому, что температура газов перед входом в турбину составляет уже от 1100 до $1315^{\circ} \mathrm{C}$, а скорость потока горячих газов - $300 \mathrm{M} / \mathrm{c}$.

При использовании чистых видов топлива, например в авиационных двигателях, с содержанием серы менее 0,25 масс. \% и смол до 1 мг на 100 мл топлива поверхности лопаточного аппарата подвергаются высокотемпературному окислению (ВТО). Эрозионное воздей- 
ствие газового потока и термоциклирование могут ускорять окисление, вызывая растрескивание и осыпание окалины. Для судовых и стационарных ГТУ, работающих на более дешевых видах топлива с содержанием серы до 1 масс. \%, наиболее характерно коррозионноэрозионное повреждение лопаточного аппарата в присутствии расплава солей, главным образом сульфата натрия. Подобный вид повреждений встречается и на лопатках авиационных турбин при эксплуатации в морских условиях, когда коррозионные реагенты (брызги морской воды с растворенными в ней солями и твердыми частицами) попадают вместе с воздухом в проточную часть. Такие сложные условия эксплуатации являются одним из основных факторов, определяющих выбор направлений развития жаропрочных сплавов. Таким направлением является выбор оптимальной системы легирования в комплексе с нанесением защитных покрытий. Современные жаропрочные материалы для газотурбинных установок представляют собой композиции сплав - покрытия, в которых главенствующую роль играет жаропрочный сплав, поскольку его разупрочнение при превышении допустимых рабочих температур приводит к разрушению всей детали, в том числе и защитного покрытия.

Жаростойкие покрытия применяются для защиты поверхности лопаток газовых турбин (ГТУ) и газотурбинных двигателей (ГТД) разного назначения $[3,4]$. Основной функцией этих покрытий является повышение жаро- и коррозионной стойкости за счет определенного запаса алюминия, который должен как можно более длительное время обеспечивать образование плотной защитной окисной пленки $\alpha-\mathrm{Al}_{2} \mathrm{O}_{3}$ на поверхности детали. $\mathrm{C}$ точки зрения получения высоких показателей жаростойкости в настоящее время достигнуты определенные успехи, которые, однако, не гарантируют надежную эксплуатацию таких покрытий в течение заданного ресурса. Как известно $[3,4,6]$, моноалюминиды $(\mathrm{Fe}, \mathrm{Ni}, \mathrm{Co})$ обладают низкой пластичностью. Однако следует ожидать, что показатели прочности и пластичности алюминидных покрытий должны быть выше, чем у чистых интерметаллидов, поскольку термодиффузионное покрытие наследует свойства жаропрочного никелевого сплава или стали, заложенные в ходе технологической обработки. Структурная наследственность термодиффузионных алюминиидных покрытий проявляется в сохранении тугоплавких соединений, например карбидов $\mathrm{TiC}, \mathrm{NbC}, \mathrm{WC}, \mathrm{MoC}, \mathrm{Cr}_{23} \mathrm{C}_{6}$, во внешней и диффузионной зонах [7]. Кроме того, внешняя зона таких покрытий оказывается легированной элементами защищаемого сплава $[8,9]$, что безусловно сказывается на защитных свойствах.

В настоящее время накоплен большой опыт эксплуатации покрытий на основе интерметаллидов $\mathrm{FeAl}, \mathrm{NiAl}$ и $\mathrm{CoAl}$, что позволяет сформулировать общие закономерности их повреждений и наметить пути повышения долговечности, несмотря на существенно отличающиеся условия нанесения этих покрытий и их эксплуатации.

Цель данного исследования состоит в анализе основных видов эксплуатационной повреждаемости покрытий на основе алюминидов разного состава, нанесенных разными способами, и определении основных путей повышения долговечности.

\section{2. Материалы и основные методы исследований}

В работе были исследованы покрытия на основе алюминидов, нанесенные разными способами на стали и жаропрочные никелевые сплавы, химические составы которых приведены в табл. 1. Покрытия наносили термодиффузионным способом в контейнерах с порошковой смесью $[3,8]$ или из шликера $[9,13]$, а также методом электронно-лучевого и атомноионного напыления $[2,4]$. Микроструктуру покрытий исследовали методами оптической металлографии (микроскоп NEOPHOT-21) при увеличениях от 200 до 500 и растровой электронной микроскопии (микроскоп TESCAN VEGA II XMU) при увеличениях до 5 тыс.). Химический состав покрытий оценивали методом локального микрорентгеноспектрального анализа, используя энергодисперсионную приставку OXFORD INCA.

Испытания на жаростойкость проводили при $950{ }^{\circ} \mathrm{C}$ в печной атмосфере с промежуточными охлаждениями с печью и взвешиванием образцов с покрытиями в предварительно

Pugacheva N. B. / Current trends in the development of heat-resistant coatings based on iron, 
прокаленных алундовых тиглях. Длительность испытаний - 1000 часов. Коррозионные испытания проводили по оригинальной методике в расплаве смеси солей 75 мас. $\% \mathrm{Na}_{2} \mathrm{SO}_{4}$ и 25 мас. \% $\mathrm{NaCl}$ при температуре $950{ }^{\circ} \mathrm{C}$. Коррозионную стойкость оценивали по значениям максимальной глубины проникновения продуктов коррозии в сплав и по скорости коррозии, которую рассчитывали по методике, приведенной в работах $[16,17]$.

Таблица 1 - Химический состав жаропрочных никелевых сплавов (мас. \%)

\begin{tabular}{|c|c|c|c|c|c|c|}
\hline Сплав & $\mathrm{Cr}$ & $\mathrm{Al}$ & $\mathrm{Ti}$ & $\mathrm{Mo}$ & $\mathrm{W}$ & Co \\
\hline ЭИ893 & $15-17$ & $1,2-1,6$ & $1,2-1,4$ & $3,5-4,5$ & $9-10$ & - \\
\hline ЭИ929 & $9-12$ & $3,6-4,5$ & $1,4-2,0$ & $4-6$ & $4,5-6,5$ & $12-16$ \\
\hline ЖС6К & $9,5-12,0$ & $5,0-6,0$ & $2,5-3,2$ & $3,5-4,5$ & $4,5-5,5$ & $4,0-5,5$ \\
\hline ЗМИ-3 & $12,5-14,0$ & $2,6-3,3$ & $4,5-5,3$ & $1,5-2,0$ & $4,0-5,0$ & $5,0-6,0$ \\
\hline ЦНК-7 & $14-15,5$ & $3,5-4,0$ & $3,5-4,0$ & $0,2-1,0$ & $6,5-8,0$ & $8,0-10,0$ \\
\hline ЭП539ЛМ & $17-19$ & $3,0-4,0$ & $2,0-3,0$ & $5-7$ & $2,5-4,0$ & $4-6$ \\
\hline ЧС70-ВИ & $15-16,5$ & $2,8-3,1$ & $4,3-5,1$ & $1,0-2,0$ & $5,0-6,0$ & $11,0-13,0$ \\
\hline ЖС6У & $8-9,5$ & $5,1-6,0$ & $2,0-2,9$ & $1,2-2,4$ & $9,5-11,0$ & $9-10,5$ \\
\hline ЖС-16 & $4,5-5,4$ & $5,3-6,2$ & $0,7-1,2$ & - & $15,3-16,5$ & $5,7-10,0$ \\
\hline
\end{tabular}

Сравнительную оценку стойкости покрытий к растрескиванию при смене температур определяли по результатам термоциклирования образцов по двум режимам: 1 - нагрев до $900{ }^{\circ} \mathrm{C}$, выдержка 15 мин, охлаждение в холодной воде; 2 - нагрев до $1100{ }^{\circ} \mathrm{C}$, выдержка и охлаждение такие же. За критерий термостойкости покрытий выбраны количество циклов до появления первых трещин и количество трещин на единице длины поверхности после 25 циклов испытаний. Проведена также оценка характерных видов дефектов покрытий после нанесения и эксплуатации.

\section{3. Обсуждение результатов исследований}

\section{1 Анализ структуры и защитных свойств диффузионных покрытий}

При формировании диффузионных покрытий в результате химико-термической обработки (ХTO) структура, фазовый состав и свойства поверхностных слоев определяются составом материала основы. На сталях формируются покрытия, состоящие из алюминидов железа, на никелевых сплавах - из алюминидов никеля (рис. 1). Толщина термодиффузионных алюминидных покрытий, получаемых насыщением в порошковых смесях, на сталях обычно составляет от 70 до 180 мкм, что в $2-3$ раза превышает толщину покрытий на никелевых сплавах.

В исходном состоянии алюминидные покрытия на сталях состоят из внешней зоны алюминида $\mathrm{FeAl}$, затем следует зона смеси $\mathrm{Fe}_{3} \mathrm{Al}$ и $\alpha$-твёрдого раствора алюминия в ОЦК решётке железа, а на границе со сплавом образуется $\alpha$-твёрдый раствор (рис. 2 a). Максимальное содержание алюминия на уровне 28 - 30 мас. \% наблюдается во внешней зоне толщиной 20 - 25 мкм, далее концентрация алюминия уменьшается до 12 мас. \% во второй зоне и плавно переходит в третьей зоне к содержанию алюминия в стали-основе (рис. 2 б). Как показали исследования по термодиффузионному алитированию ферритных сплавов Х15Ю5, $\mathrm{X} 17 Ю 5$ и X20Ю5 [10], возможно, что в переходной ферритной зоне покрытий на границе со сталью-основой $B 2$ фаза FeAl присутствует в виде доменов. 
open-access journal
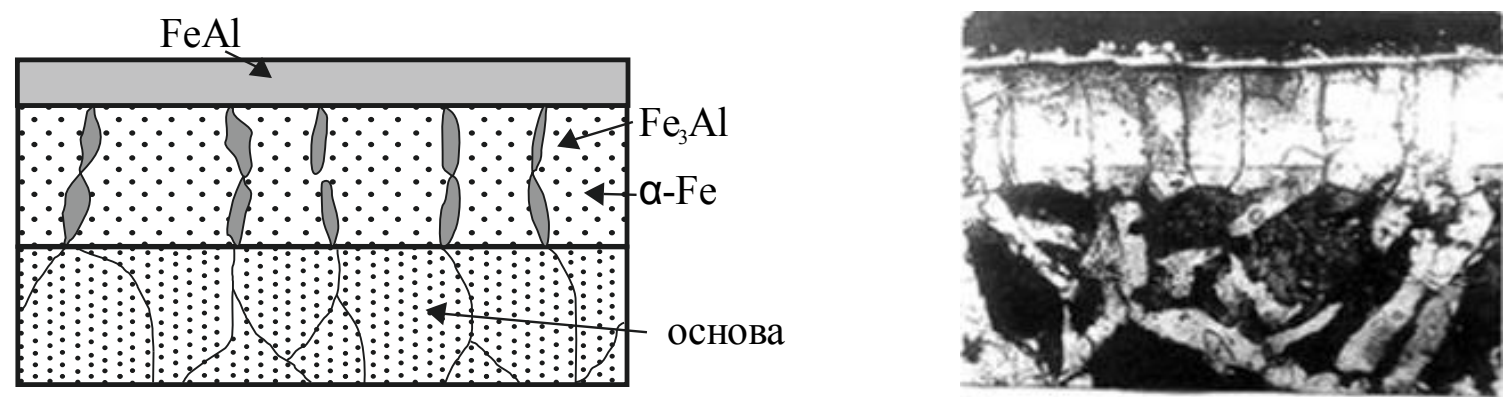

$a$
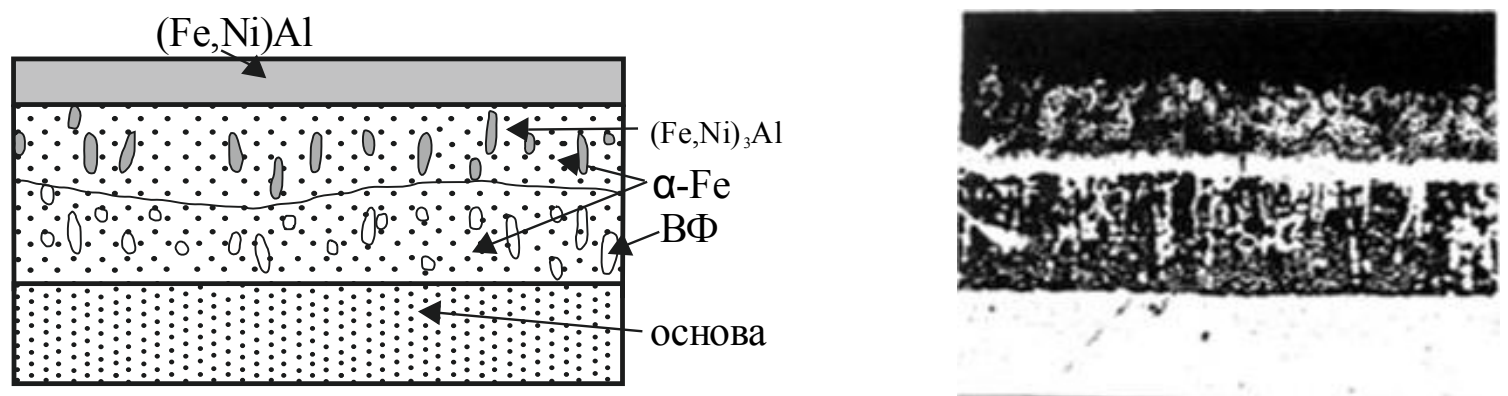

$\sigma$
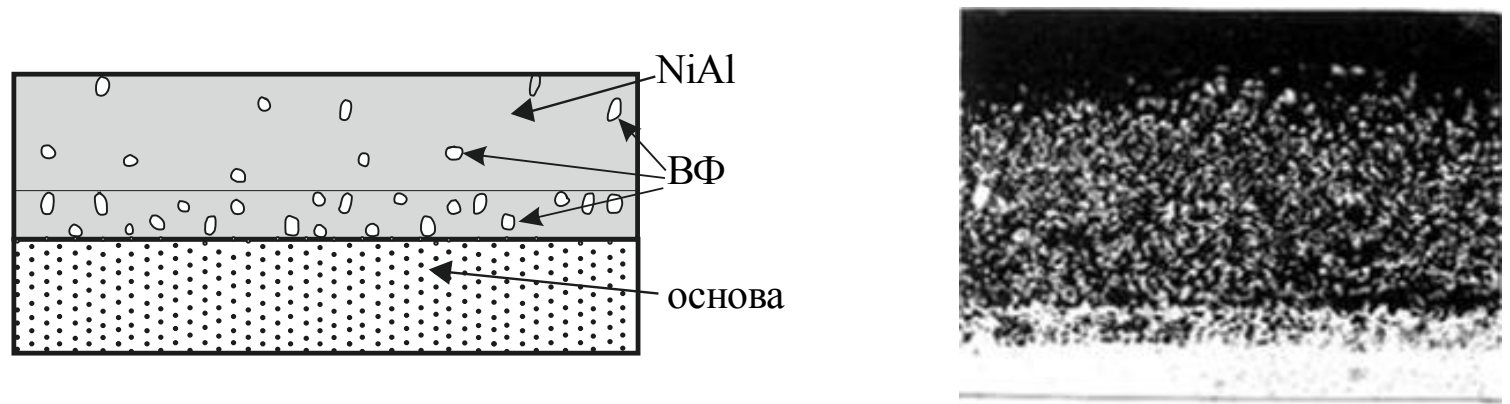

B

Рис. 1. Схемы и микроструктуры диффузионных алюминидных покрытий на сталях и никелевых сплавах: $a$ - на углеродистых сталях; $\sigma$ - на аустенитных сталях;

в - на никелевых сплавах

Если активность насыщающих порошковых смесей мала, то при формировании покрытия заметный вклад вносит диффузия железа или никеля из основы в поверхностные слои, происходит небольшое (на 10 - 20 мкм) увеличение толщины детали. Начальную поверхность детали до алитирования хорошо видно на нетравлёных шлифах - рис. 3 a. При эксплуатации при температурах, близких к климатическим, как например золотниковой пары, такие покрытия чаще всего растрескиваются под действием сил трения и циклических нагрузок (рис. 3 б). Причём трещины образуются во внешней зоне покрытия. Это обусловлено высокой твердостью этого слоя $(600$ HV 0,05), а также наличием микропор, которые могли образоваться вследствие нескомпенсированной диффузии железа к поверхности и алюминия вглубь стали.

После коррозионных испытаний в условиях климатической влажности при температурах около $60{ }^{\circ} \mathrm{C}$ не происходит уменьшения концентрации алюминия в покрытии, значения микротвёрдости после испытаний не изменяются, поскольку диффузионные процессы между покрытием и основой, а также расходование алюминия на образование поверхностной пленки $\alpha-\mathrm{Al}_{2} \mathrm{O}_{3}$ отсутствуют. Наблюдается лишь более развитая по сравнению с исходным состоянием пористость тонкой внешней зоны на глубине не более 15 - 20 мкм от поверхности

Pugacheva N. B. / Current trends in the development of heat-resistant coatings based on iron, 
open-access journal

(рис. 3 в). Следов окисления стали с образованием железосодержащих оксидов или шпинелей не обнаружено.

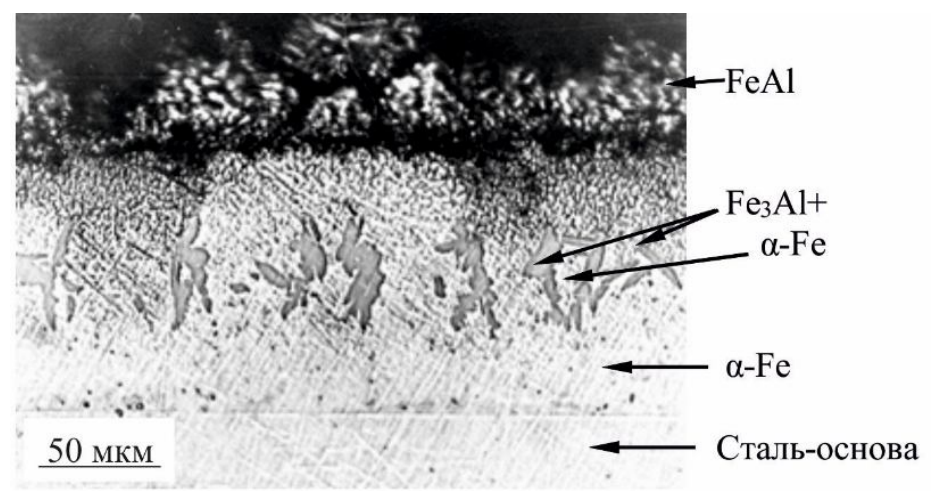

$a$

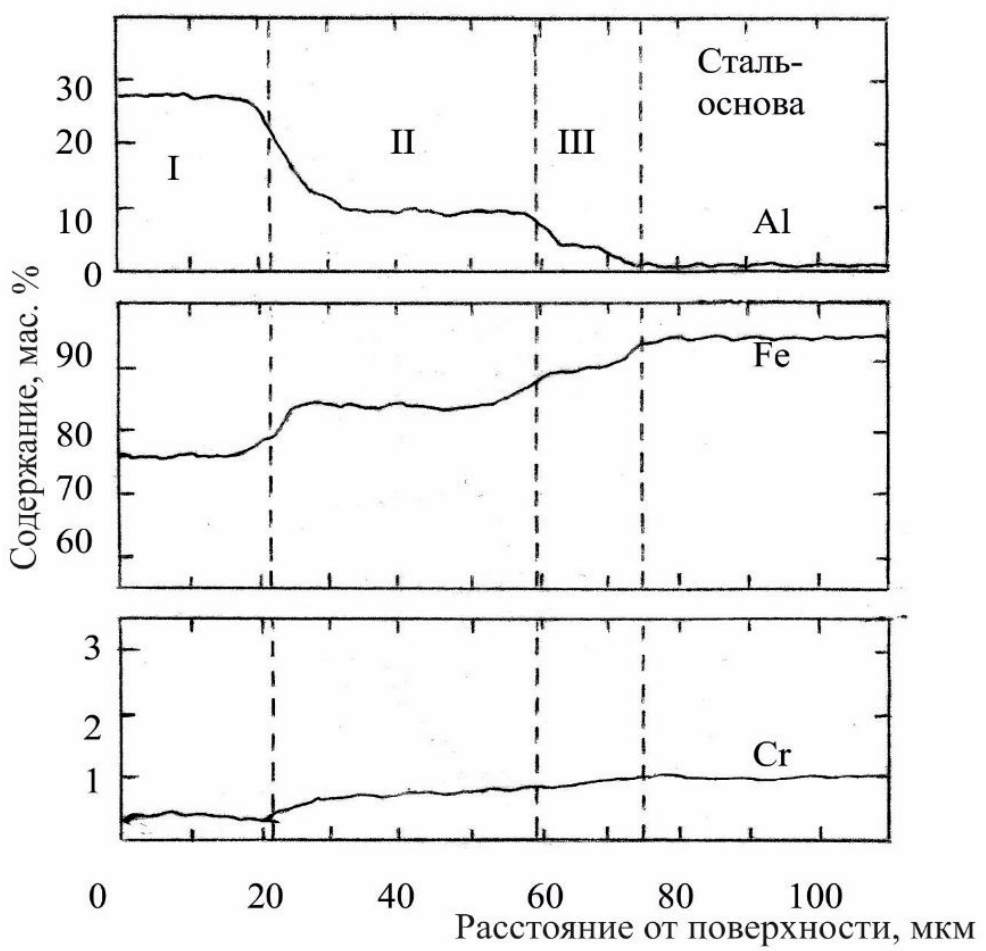

6

Рис. 2. Микроструктура ( $a$ ) и характер распределения элементов (б) по толщине диффузионного алюминидного покрытия на стали $15 \mathrm{X}$

Для деталей, эксплуатируемых при климатических температурах и истирающих нагрузках, следует наносить термодиффузионные алюминидные покрытия в составах, позволяющих получать содержание алюминия на уровне 16 - 24 мас. \%, что обеспечит образование на поверхности слоя на основе алюминидов со структурой $\mathrm{DO}_{3}$ и $B 2$. Сочетание твёрдых частиц интерметаллидов железа с пластичным $\alpha$-твёрдым раствором алюминия в ОЦК решётке железа, т.е. формирование гетерофазной структуры покрытия, позволит достичь необходимый уровень стойкости к растрескиванию при истирающих и вибрационных нагрузках. Получение такого покрытия возможно при использовании шликера на основе водорастворимого хромофосфатного связующего. В промышленности хромофосфатные связующие используются для приготовления жаростойких бетонов, огнеупорных масс для футеровки печей и тепловых агрегатов, являются основой жаростойких минеральных клеев [6]. В состав связующих этого типа, как правило, входят ортофосфорная кислота $\mathrm{H}_{2} \mathrm{PO}_{4}$, полимеризующа-

Pugacheva N. B. / Current trends in the development of heat-resistant coatings based on iron, 
open-access journal

яся при медленном нагреве до температур $215-350{ }^{\circ} \mathrm{C}$ и образующая плотную эмалевидную плёнку, нерастворимую в воде, и окислы $\mathrm{Cr}_{2} \mathrm{O}_{3}, \mathrm{MgO}, \mathrm{Al}_{2} \mathrm{O}_{3}$. Хромофосфатное связующее, в отличие от органических (цапон-лак, целлюлоза и пр.), химически взаимодействует с металлическим наполнителем шликера (порошками алюминия и кремния), а также с защищаемым сплавом, что положительно влияет на эксплуатационные характеристики защитного покрытия за счёт микролегирования алюминидов магнием и хромом, а также за счёт повышения его плотности и равномерности.

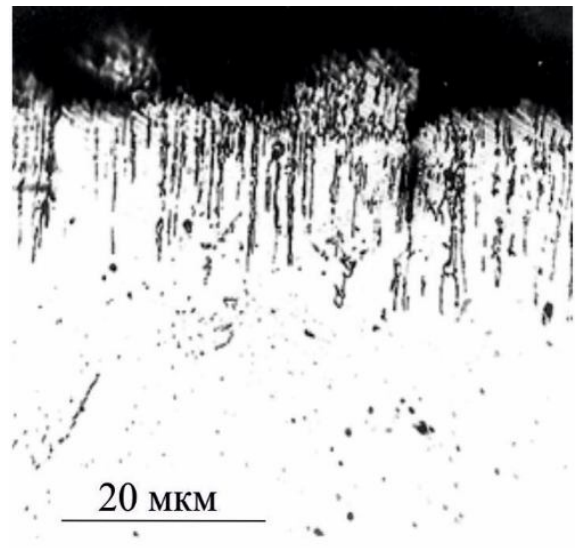

$a$
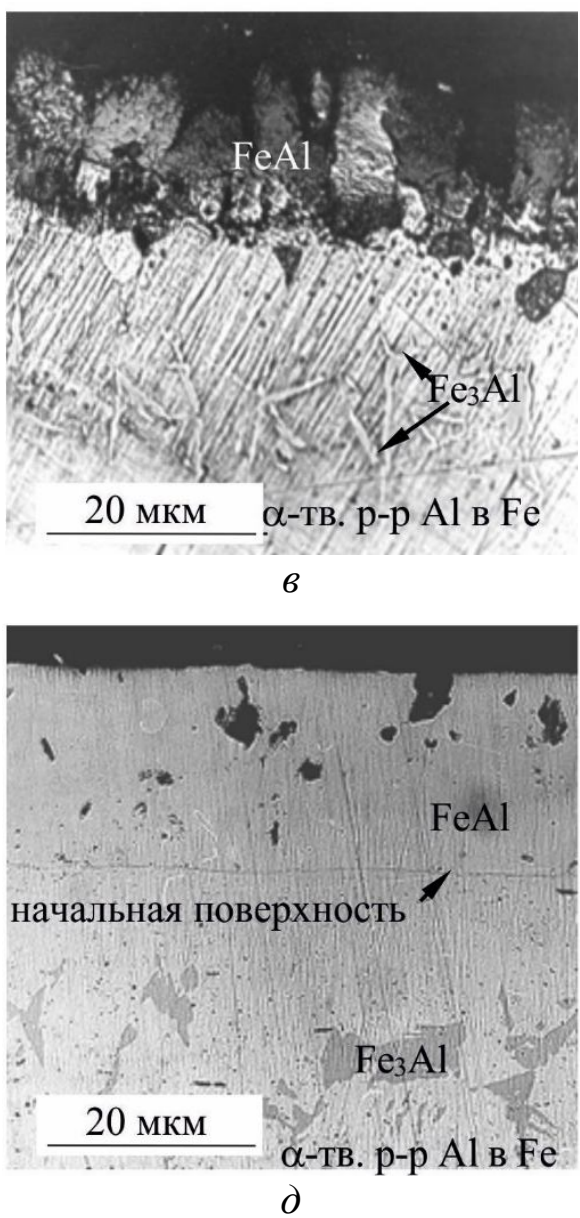

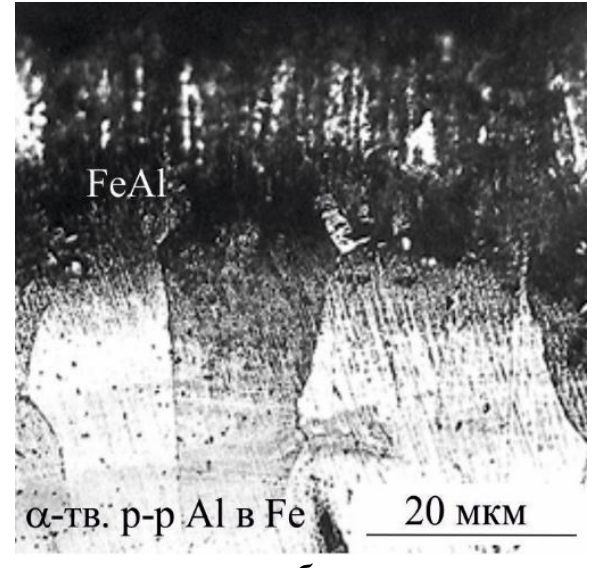

6
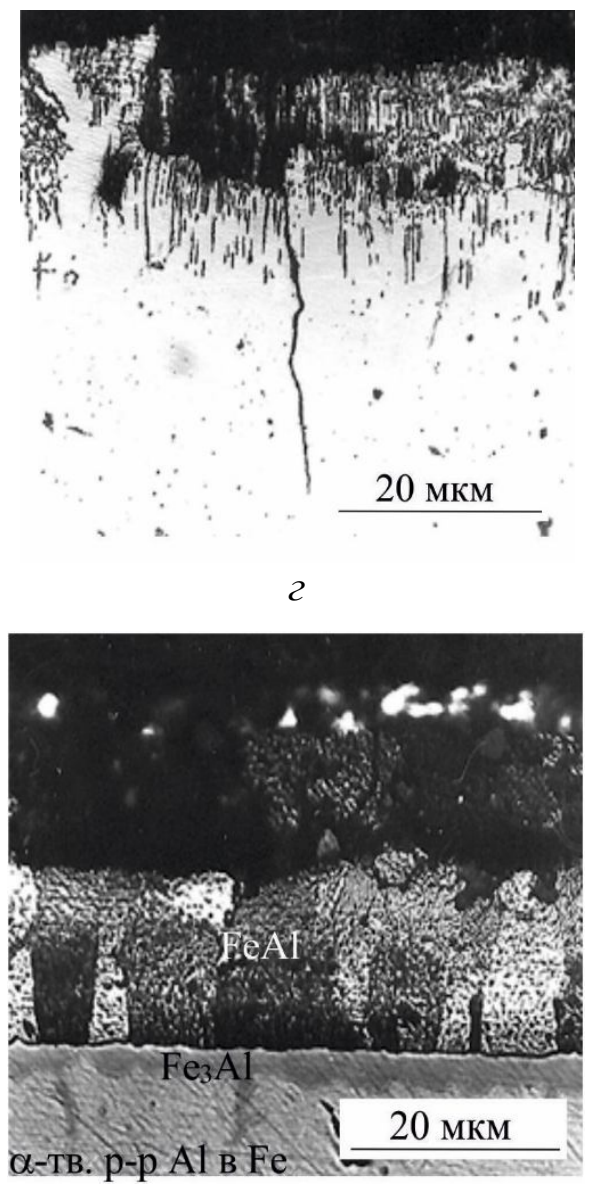

$e$

Рис. 3. Характер повреждений алюминидных диффузионных покрытий на стали $15 \mathrm{X}$ после эксплуатации в условиях трения при климатических температурах

Pugacheva N. B. / Current trends in the development of heat-resistant coatings based on iron, nickel and cobalt aluminides 
По структуре и характеру распределения элементов шликерные покрытия идентичны получаемым в контейнерах с порошковой смесью ферросплавов (рис. 4 и 5). Отличие заключается в меньшем содержании алюминия при одинаковых температурах и длительностях насыщения. Покрытие содержит магний в тонком приповерхностном слое в малых количествах (около 1 мас. \%), который можно зафиксировать при микрорентгеноспектральном анализе поверхности детали после ХТО. Данный метод нанесения покрытий может быть использован для локального алюмосилицирования, нанесения защитного слоя на крупногабаритные детали, а также в качестве ремонтной технологии. В качестве насыщающих компонентов могут быть использованы порошки алюминия и кремния или порошки ферросплавов $\mathrm{FeAl}, \mathrm{FeSi}, \mathrm{Fe}-\mathrm{Al}-\mathrm{Si}$ или Fe-Al-Si-P3M [2, 8].

Содержание алюминия и кремния в получаемых покрытиях можно менять в интервалах 16 - 25 мас. \% для алюминия и 2-6 мас. \% для кремния. Это достигается как за счёт состава шликера, так и за счет режима XТО (табл. 2). Более пластичные покрытия с плотной внешней зоной формируются при отжиге детали с нанесённым шликерным слоем в герметичном контейнере с инертным порошком $\mathrm{Al}_{2} \mathrm{O}_{3}$.

Таблица 2 - Толщина, микротвёрдость и химический состав шликерных покрытий на никелевом сплаве ЭП539ЛМ после отжига при $950{ }^{\circ} \mathrm{C}, 4$ ч

\begin{tabular}{|c|c|c|c|c|c|c|c|c|}
\hline \multirow{2}{*}{$\begin{array}{c}\text { Кол-во } \\
\text { Al-Si, } \\
\text { мас. } \%\end{array}$} & \multirow{2}{*}{$\begin{array}{c}\text { Толщина } \\
\text { покры- } \\
\text { тия, мкм }\end{array}$} & $\begin{array}{c}\text { Микротвёрдость, } \\
\text { МПа }\end{array}$ & \multicolumn{7}{c|}{ Хншняя } \\
зона & $\begin{array}{c}\text { Диф. } \\
\text { зона }\end{array}$ & $\mathrm{Al}$ & $\mathrm{Si}$ & $\mathrm{Cr}$ & $\mathrm{Ti}$ & Со \\
\hline \multicolumn{8}{|c|}{ Отжиг в вакууме } \\
\hline $90-10$ & $60-65$ & 6200 & 9200 & 25 & 4 & 8 & 0,7 & 4 \\
\hline $85-15$ & $50-55$ & 6350 & 9500 & 23 & 5 & 10 & 0,7 & 4 \\
\hline $70-30$ & $45-50$ & 6500 & 9600 & 20 & 6 & 12 & 0,5 & 5 \\
\hline $50-50$ & $30-40$ & 6500 & 10000 & 18 & 10 & 12 & 0,2 & 5 \\
\hline \multicolumn{8}{|c|}{ Отжиг в герметичном контейнере с окисью алюминия } \\
\hline $85-15$ & $50-55$ & 6000 & 8600 & 16 & 3 & 8 & 0,5 & 5 \\
\hline $70-30$ & $45-50$ & 6200 & 8800 & 15 & 5 & 10 & 0,2 & 6 \\
\hline
\end{tabular}

Совершенно в других условиях работают покрытия на лопатках стационарных газовых турбин, авиационных и корабельных ГТД. На них одновременно воздействуют высокие температуры (порядка $700-1000{ }^{\circ} \mathrm{C}$ ), высокоскоростной газовый поток продуктов сгорания топлива и вибрационные нагрузки. Поэтому к покрытиям предъявляются повышенные требования. Главные из них - высокая структурная (фазовая) термическая стабильность, прочность, пластичность и вязкость разрушения $[1,3]$. Эти свойства обеспечиваются оптимальным содержанием алюминия в покрытии, а также легированием реакционно-активными элементами, главным образом кремнием и редкоземельными металлами (Р3М) [3, 12].

Для получения высоких показателей жаро- и коррозионной стойкости первоначально стремились получать покрытия с максимально высоким содержанием алюминия (до 30 - 36 мас. \%) в смесях высокой активности (диффузионное шликерное покрытие состава $\left.35 \mathrm{Al}-1 \mathrm{Si}^{1}\right)$, что способствует его легированию хромом во внешней зоне за счет сплава основы (до 10 мас. \% для сплавов ЭП539ЛМ, ЧС70, ЗМИ-3 и т.п.). Значение микротвердости на уровне $900 \mathrm{HV}$ 0,05 должно было обеспечить стойкость к эрозионному воздействию газового потока.

1 Здесь и далее по тексту указан состав покрытий в мас. \%.

Pugacheva N. B. / Current trends in the development of heat-resistant coatings based on iron, 
opent-aCCESS jürnal
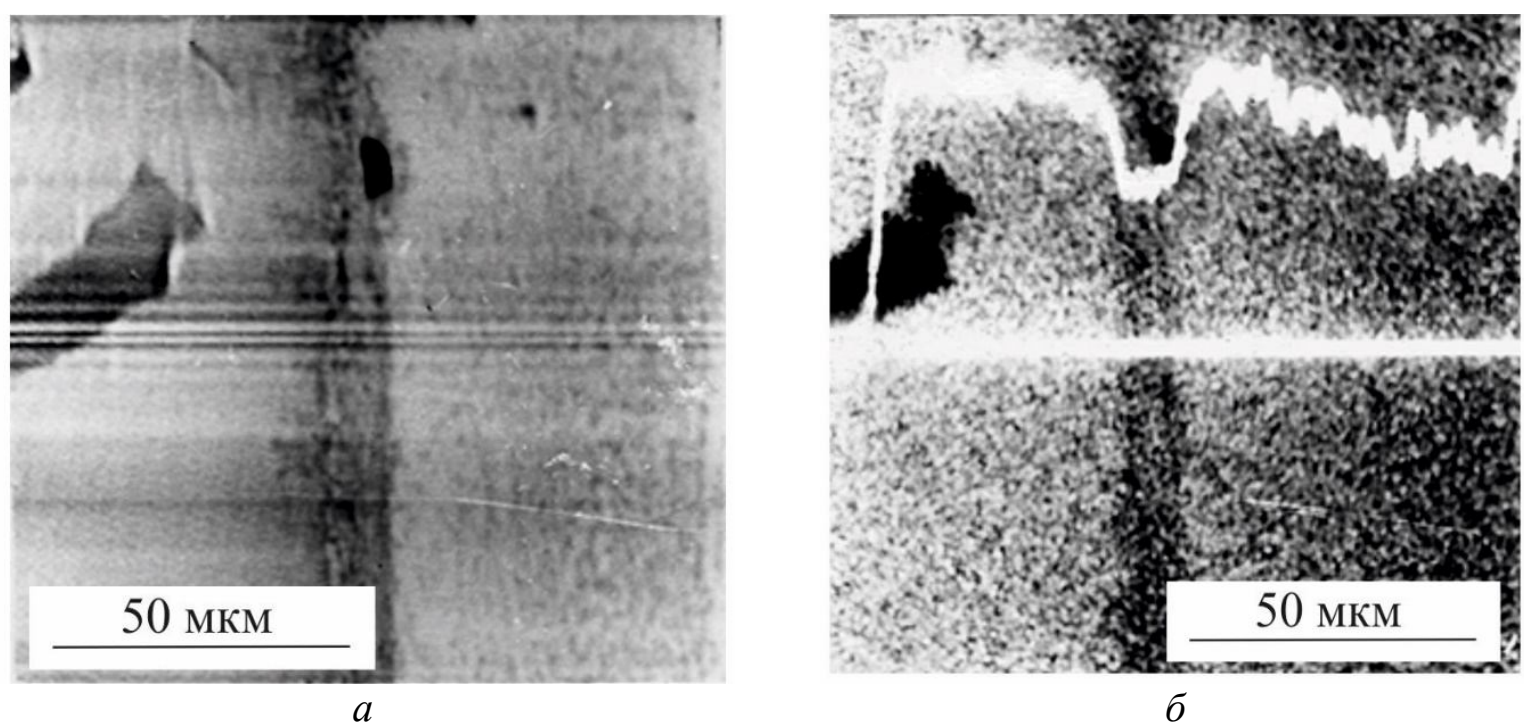

$\sigma$
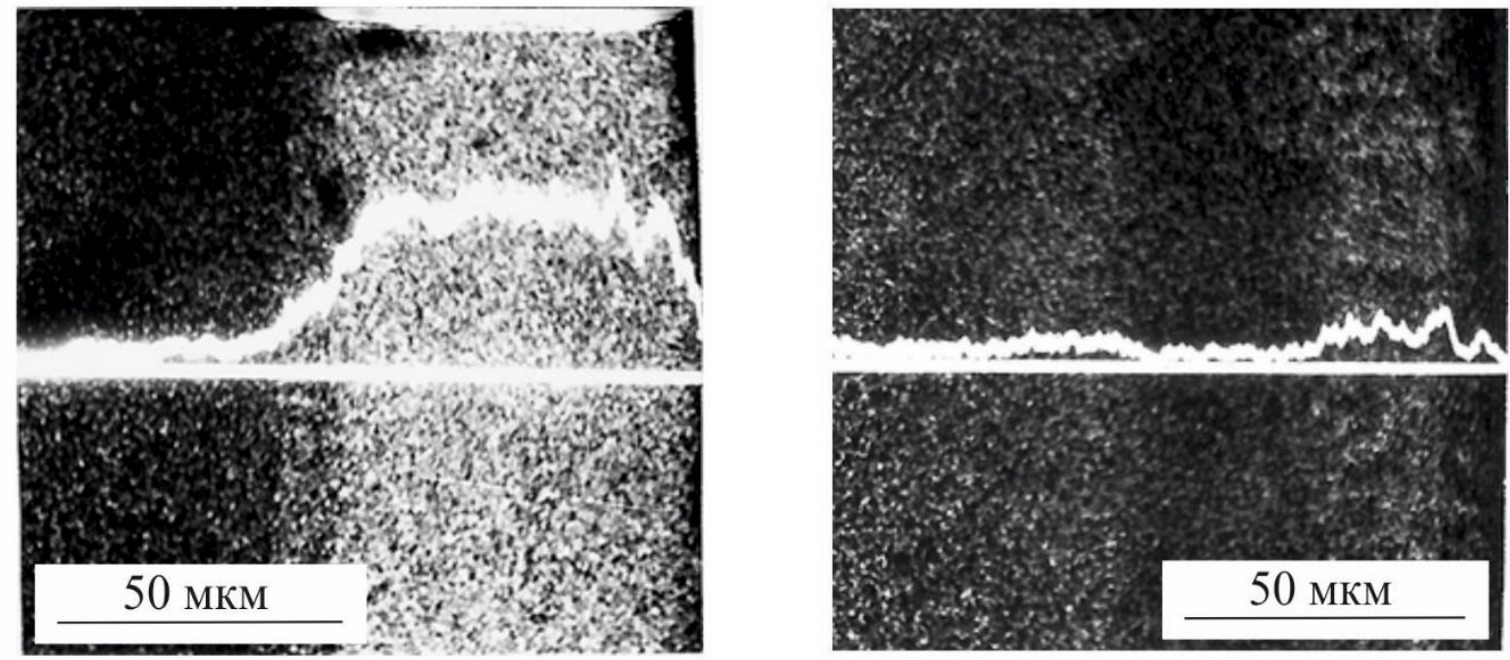

B

2
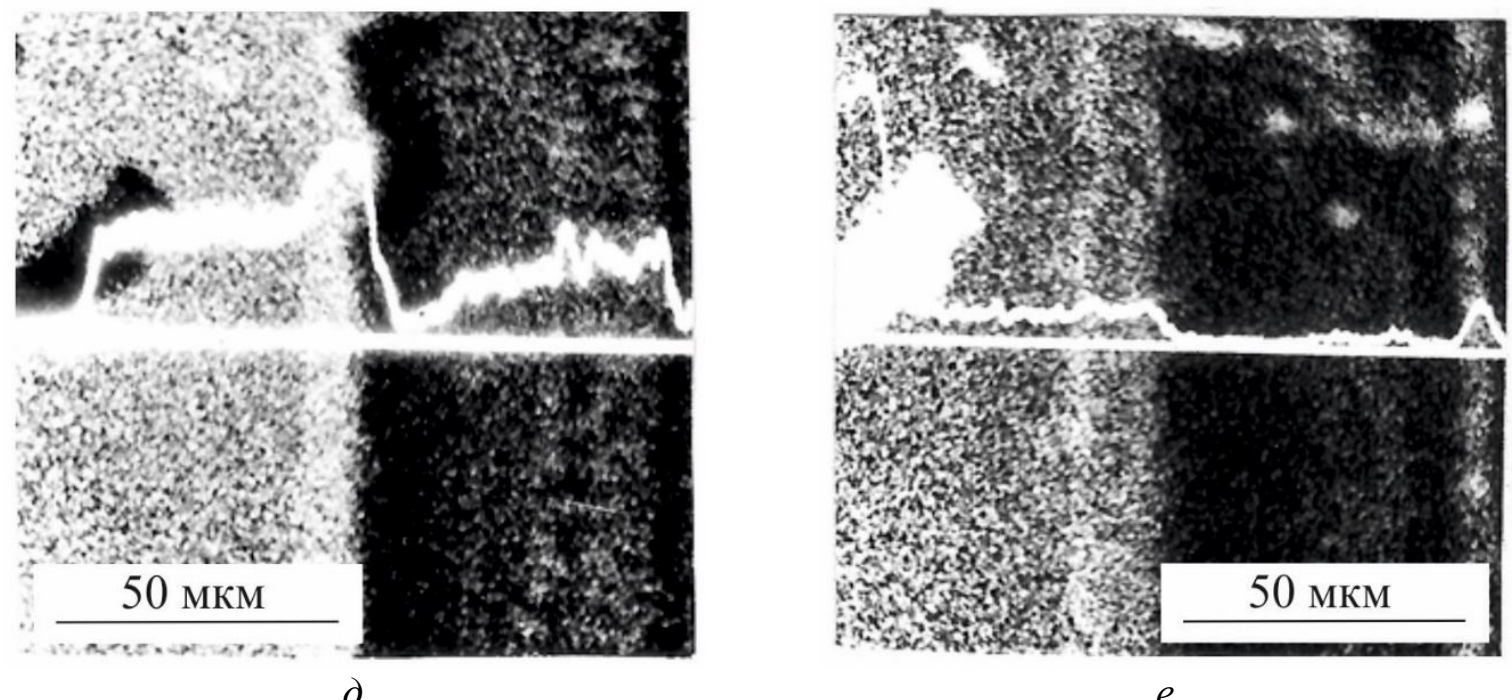

$e$

Рис. 4. Характер распределения элементов по толщине шликерного алюмлсидицидного покрытия на жаропрочном сплаве ЭП539

Pugacheva N. B. / Current trends in the development of heat-resistant coatings based on iron, nickel and cobalt aluminides 
opter-aCCeSs jürnal



$a$

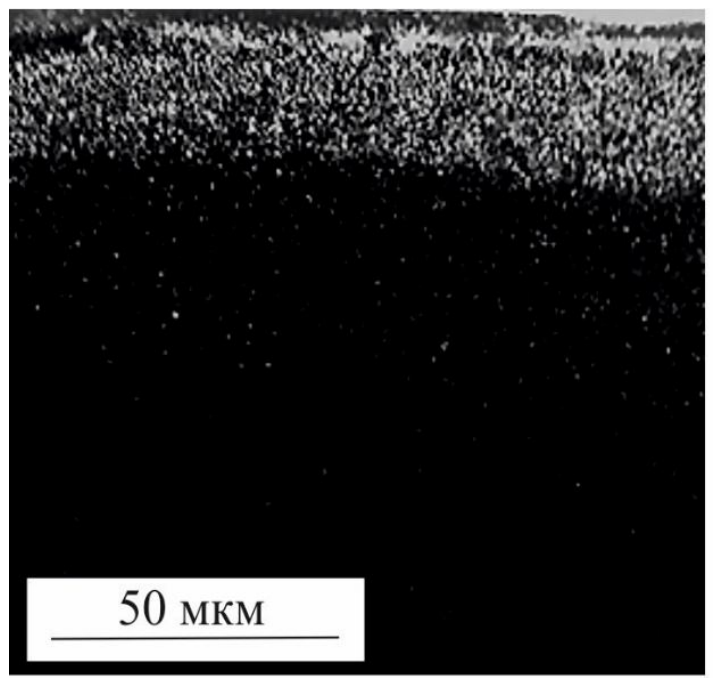

B

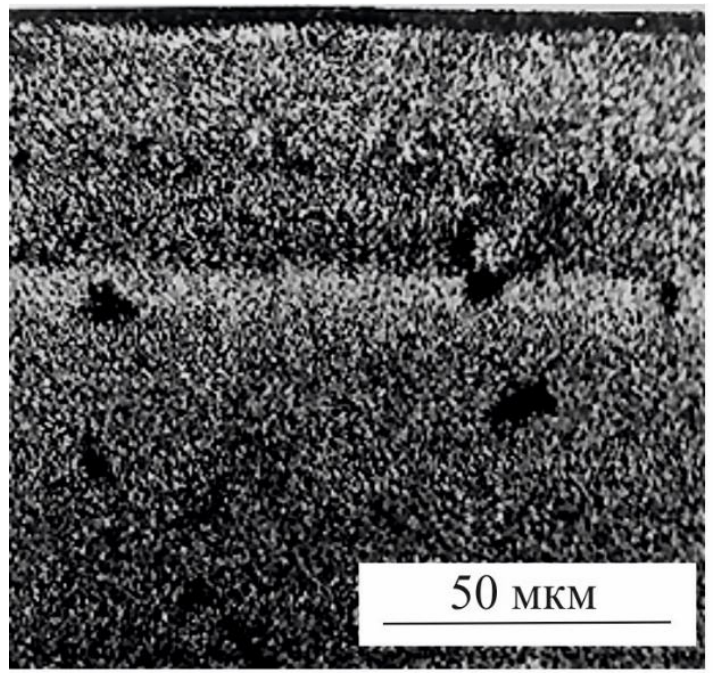

2



$\sigma$


0

$20 \quad 40 \quad 60$

Расстояние от поверхности, мкм

Рис. 5. Распределение элементов по толщине алюмосидицидного покрытия на сплаве ЧС 70

Pugacheva N. B. / Current trends in the development of heat-resistant coatings based on iron, nickel and cobalt aluminides 
Анализ характера повреждений покрытий такого состава при эксплуатации показал, что основным видом повреждений является выкрашивание внешней зоны (рис. $6 a$, б), на всей поверхности лопаток появляется интенсивный микрорельеф. Скорее всего это связанно с образованием на границе внешней и диффузионной зон крупнозернистой $\beta$-фазы (рис. 6 в), которая обладает низкой пластичностью и легко растрескивается при механических нагрузках, особенно знакопеременных [2]. Кроме того, не следует исключать возможности протекания в ней мартенситного превращения во время быстрого охлаждения лопаток при остановке турбины, что может дополнительно стимулировать образование трещин на границе внешней и диффузионной зон покрытия [14]. Нередко трещины наблюдаются в покрытии и сплаве под ним (рис. 6 г), где а результате диффузионного взаимодействия сплава и покрытия образуются игольчатые частицы б-фазы $(\mathrm{Cr}, \mathrm{Mo})_{\mathrm{x}}(\mathrm{Ni}, \mathrm{Co})_{\mathrm{y}}($ рис. $6 \partial)$.

Повысить пластичность покрытий данного класса можно за счет уменьшения содержания алюминия. При этом для сохранения высокой коррозионной стойкости целесообразно увеличить запас кремния. Легирование упорядоченной $\beta$-фазы кремнием приводит к повышению ее твёрдости и подавляет мартенситное превращение [14], что положительно влияет на термостойкость покрытия и сопротивление эрозионному выкрашиванию. Для получения таких покрытий были разработаны порошковые смеси средней активности на основе ферроалюминия и ферросилиция $[2,8]$ и температурно-временной режим XТО, которые обеспечивают формирование покрытия следующего химического состава, мас. \%: $30 \mathrm{Al}$ и $5 \mathrm{Si}$. Данный технологический процесс в течение 7 лет $(1981-1988)$ использовался на ПО “Турбомоторный завод” для нанесения покрытий на рабочие и направляющие лопатки стационарной газовой турбины ГТН-16.

Систематические исследования показали, что содержание кремния на уровне 4 - 5 мас. \% вполне достаточно для проявления в полной мере влияния этого элемента на стабильность $\beta$-фазы. Так, длительная эксплуатация - более 11 тыс. ч - рабочих и направляющих лопаток с покрытием данного состава в стационарной газовой турбине ГТН-16 не привела к существенным изменениям структуры и химического состава поверхностного слоя практически по всему периметру лопаток (рис. 7 ). Толщина покрытия на рабочих лопатках составила от 60 до 80 мкм (при исходной толщине 55-60 мкм). Во внешней зоне сохранилась мелкодисперсная $\beta$-фаза с содержанием алюминия 23 - 25 мас. \%, а кремния около 2 мас. \%; микротвердость 750 - 800 HV 0,05.

На входных кромках рабочих лопаток, наиболее подверженных воздействию скоростного газового потока, часть внешней зоны покрытия выкрошена, но сохранившийся алюмосилицированный слой толщиной 50 мкм надежно предохраняет поверхность от газовой коррозии (рисунок 7 б). Только вблизи участка эрозионного выкрашивания части покрытия наблюдали более крупные $\beta$-зерена (рис. 76, ). На отдельных участках спинки рабочих лопаток отмечено появление термоусталостных трещин (рисунок 7 г). Трещины, как правило, зарождаются в диффузионной зоне на границе между силициидами и $\beta$-фазой вследствие различий коэффициентов термического расширения (к.т.р.) $\alpha_{\mathrm{T}}$. Если для алюминида $\mathrm{NiAl} \alpha_{\mathrm{T}}$ составляет $15,1 \cdot 10^{-6} \mathrm{~K}^{-1}$, то для силицида $\mathrm{Cr}_{5} \mathrm{Si}_{3}-10,6 \cdot 10^{-6} \mathrm{~K}^{-1}$ [6]. В некоторых случаях наблюдается проникновение трещин в сплав - основу. Развития процессов газовой коррозии вдоль термоусталостных трещин в покрытии не наблюдается. 
opent-aCCESS jürnal
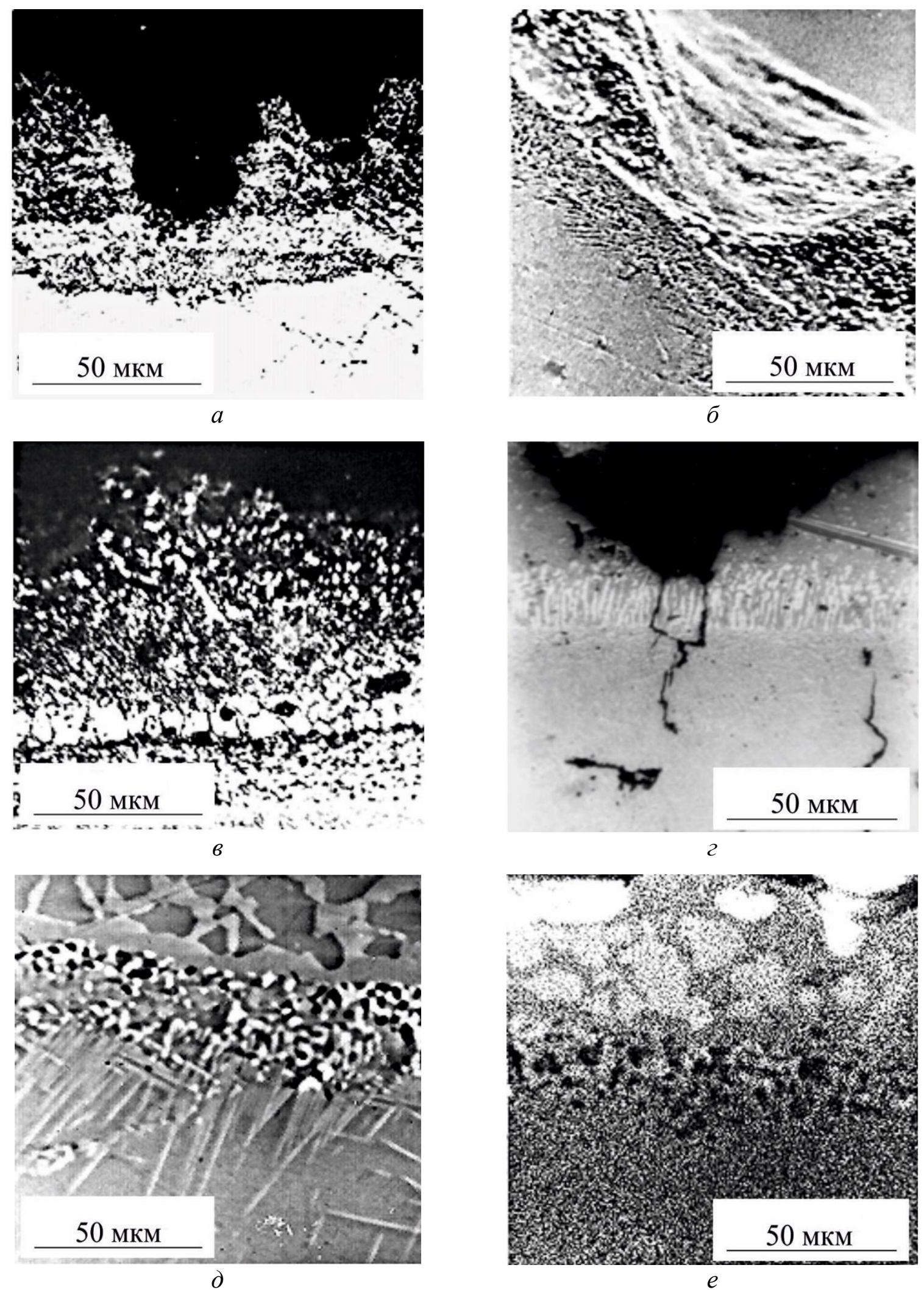

Рис. 6. Характер повреждений алюминидных покрытий на лопатках судового ГТД после эксплуатации 
open-recess journal

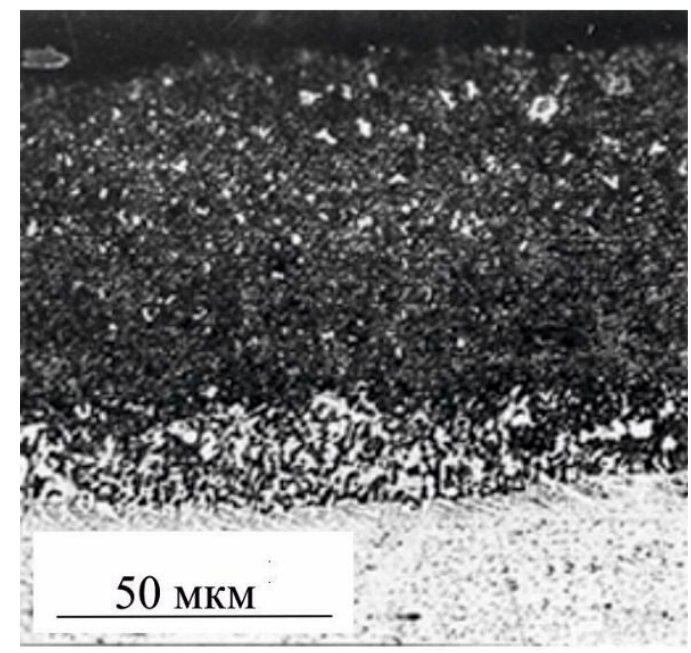

$a$
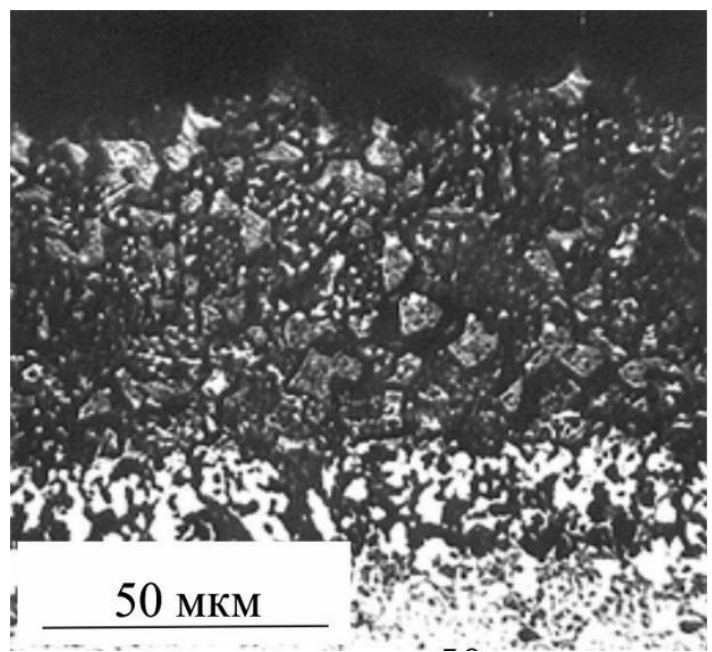

B
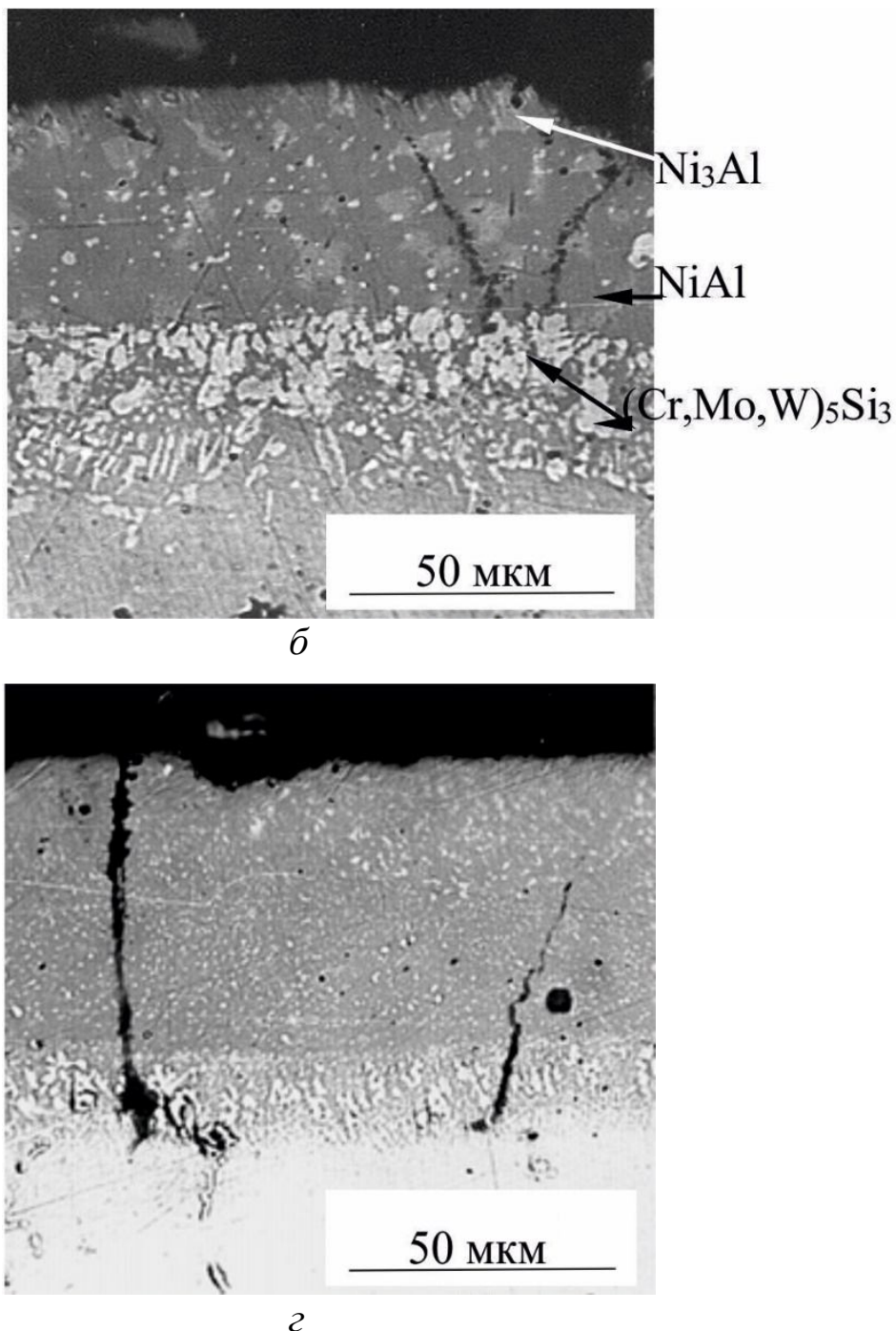

Рис. 7. Характер повреждений алюмосилицидного покрытия на лопатках стационарной ГТУ после эксплуатации

Силициды, образующиеся в покрытии 30Al-5Si на жаропрочных никелевых сплавах, по данным рентгеноструктурного и микрорентгеноспектрального анализа, идентифицированы как $\mathrm{Cr}_{5} \mathrm{Si}_{3}, \mathrm{Mo}_{5} \mathrm{Si}_{3}, \mathrm{~W}_{5} \mathrm{Si}_{3}, \mathrm{Nb}_{5} \mathrm{Si}_{3}, \mathrm{Ti}_{5} \mathrm{Si}_{3}[2,7]$, имеющие тетрагональные решётки, в которых атомы кремния образуют двумерные сетки, что придаёт соединениям сильную ковалентную составляющую межатомной связи, а следовательно, обусловливает значительные отличия этих соединений по теплофизическим свойствам от интерметаллидов, составляющих основу покрытия.

Уже после 10 ч выдержки при температуре $1100{ }^{\circ} \mathrm{C}$ и 50 ч при $800{ }^{\circ} \mathrm{C}$ кремний перераспределяется из внешней зоны, где он присутствовал в виде твердого раствора в $\beta$-фазе $\mathrm{NiAl}$ в количестве около 5 мас. \%, в диффузионную зону, образуя силициды $\mathrm{Cr}_{5} \mathrm{Si}_{3}, \mathrm{Mo}_{5} \mathrm{Si}_{3}$, $\mathrm{W}_{5} \mathrm{Si}_{3}$. Таким образом, в течение всего срока эксплуатации лопаток турбины ГТН-16 количество кремния во внешней зоне не превышало 0,5 мас. \%. Сохранение мелкодисперсной $\beta$-фазы с содержанием алюминия на уровне 22 - 25 мас. \% в течение 11200 ч свидетельствует о том, что даже такого малого количества кремния вполне достаточно для проявления в полной мере его положительного влияния на структурную стабильность.

Более высокое содержание кремния в шликерных покрытиях состава 20Al-10Si при снижении количества алюминия приводит к росту значений микротвердости внешней

Pugacheva N. B. / Current trends in the development of heat-resistant coatings based on iron, 
(порядка $1000 \mathrm{HV} \mathrm{0,05)} \mathrm{и} \mathrm{диффузионной} \mathrm{(до} 1200 \mathrm{HV}$ 0,05) зон [7, 13]. Кремний может повысить микротвердость как за счет образования значительного количества силицидов тугоплавких элементов в защитном слое, так и за счёт легирования самой $\beta$-фазы. Известно [12], что в $\beta$-фазе кремний проявляет себя как аналог алюминия и образует твердый раствор замещения. При этом происходит уменьшение периода решётки $\beta$-фазы (Гольдшмидтовские атомные радиусы алюминия 0,140 нм и кремния 0,131 нм [6]). Искажение кристаллической решетки за счет замены атомов алюминия атомами кремния, а также усиления локализации связи обусловливают повышение значений микротвердости $\beta$-сплавов при введении в них кремния.

Исследование повреждаемости шликерного покрытия 20Al-10Si показало, что снижение содержания алюминия не обеспечило высокой долговечности таких покрытий. После

50 - часовых наработок в составе ГТД наблюдаются существенные повреждения покрытия. Необоснованно высокое содержание кремния в слое привело, во-первых, к охрупчиванию алюмосилицидного слоя, во-вторых, к еще большему снижению диффузионной стабильности даже по сравнению с покрытиями с 35 мас. \% Al и 1 мас. \% Si. O повышенной хрупкости покрытий 20Al-10Si свидетельствуют множественные выкрашивания внешней зоны под действием скоростного газового потока (рис. 8 a). Наиболее подвержено растрескиванию и выкрашиванию покрытие на входных кромках исследованных рабочих лопаток.

Сколы покрытия облегчаются образованием радиальных термоусталостных трещин как во внешней, так и в диффузионной зонах (рис. 8 б, в). Принято считать, что появление таких трещин в алюминидных покрытиях чаще всего происходит при содержании алюминия более 31 мас. \% [9]. Однако повышенная легированность $\beta$-фазы в покрытиях 20Al-10Si кремнием, который сохраняется в ней в количестве 3 мас.\% даже после 1800 - часовой эксплуатации, приводит к образованию термических трещин при содержании алюминия 20 мас. \%.

Высокая концентрация кремния стимулирует формирование в защитном слое силицидов $\mathrm{M}_{5} \mathrm{Si}_{3}$, причем по объёму они распределены неравномерно и наибольшее количество частиц сосредоточено в диффузионной зоне покрытия. Как уже отмечалось, теплофизические свойства этих силицидов и алюминида $\mathrm{NiAl}$ существенно отличаются, что способствует зарождению микротрещин на межфазных границах при резких сменах температур. Проведение даже одного цикла нагрев - охлаждение (режим $20 \leftrightarrow 900{ }^{\circ} \mathrm{C}$, охлаждение на воздухе) для лопаток с этим покрытием в исходном состоянии привело к образованию в диффузионной зоне первых микротрещин (рис. 8 б). Повышенная хрупкость $\beta$-фазы, легированной кремнием, способствует быстрому росту микротрещин на всю глубину алюмосилицированного слоя. Следует подчеркнуть, что с увеличением времени наработки глубина проникновения трещин в сплав-основу почти не увеличивается, происходит их торможение на границе с жаропрочным никелевым сплавом (рис. 8 в).

Исследования покрытий 20Al-10Si на лопатках ГТД после эксплуатации в разных условиях и режимах работы показали, что в большинстве случаев во внешней зоне сохраняется мелкодисперсная $\beta$-фаза с содержанием алюминия $(18-20)$ мас. \%, кремния 3 мас. \% и микротвердостью 800 - 900 HV 0,05. Этот факт, а также отсутствие обедненных зон по краям термоусталостных трещин, свидетельствует о слабом развитии процесса окисления и высоком запасе жаростойкости этого покрытия при обычных рабочих температурах.

В то же время высокой структурной стабильности при имеющемся соотношении алюминия и кремния достигнуть не удается. Прежде всего, это связано с присутствием в $\beta$ фазе свободного кремния в количестве 3 мас. \%. Свободный кремний, как известно [12], обладает высокой диффузионной подвижностью в жаропрочных никелевых сплавах и способствует интенсивному диффузионному «рассасыванию» защитного слоя. Кроме того, кремний, присутствующий в $\beta$-фазе, ускоряет диффузионные процессы в этой структурной составляющей и способствует выделению обедненных алюминием фаз. В частности, $\gamma^{\prime}$-фаза 
open-access journal

появляется в покрытиях 20Al-10Si в процессе эксплуатации как в виде тонкого ( 5 мкм) слоя на поверхности (рис. 8 2), так и в виде отдельных зерен во всем объеме защитного слоя (рис. $8 \partial, e)$. Причём при высоких рабочих температурах $\left(1200^{\circ} \mathrm{C}\right)$ выделение $\gamma^{\prime}$-фазы происходит в виде видманштедтовой структуры (рис. 8 e).



$a$

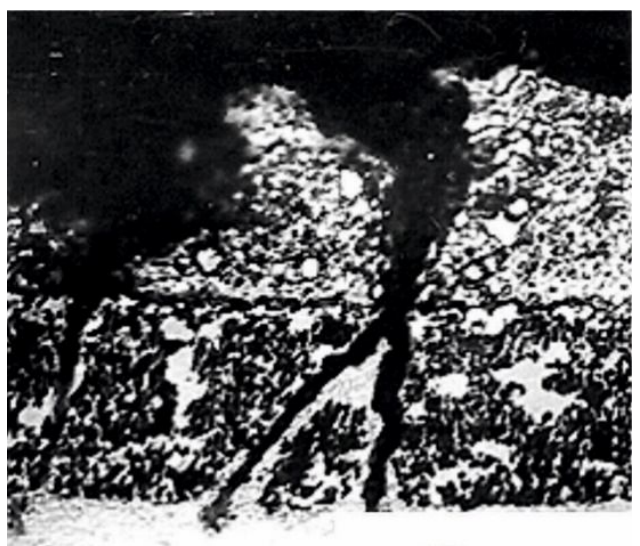

50 мкм

B

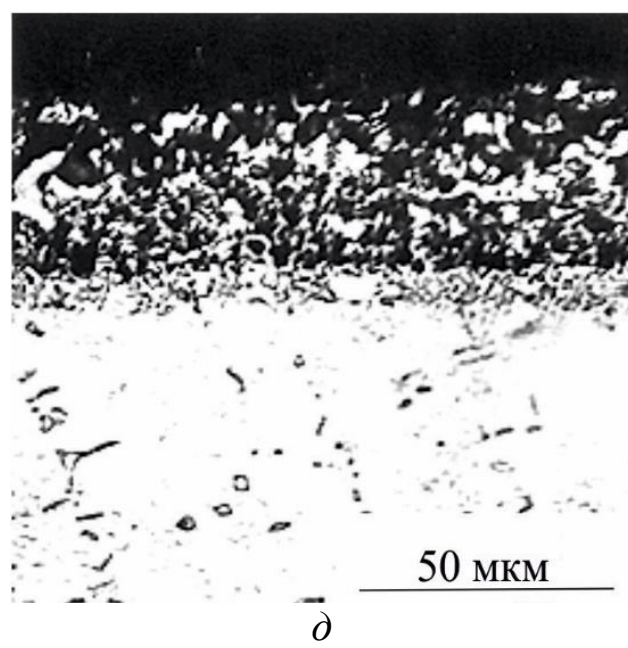

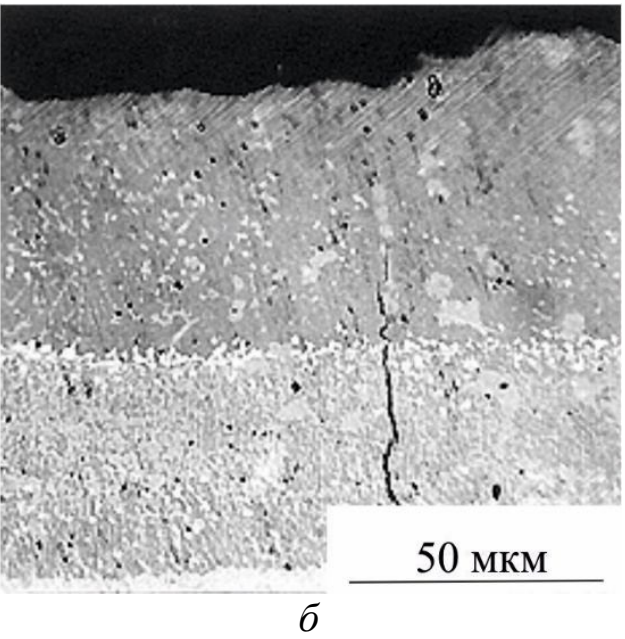
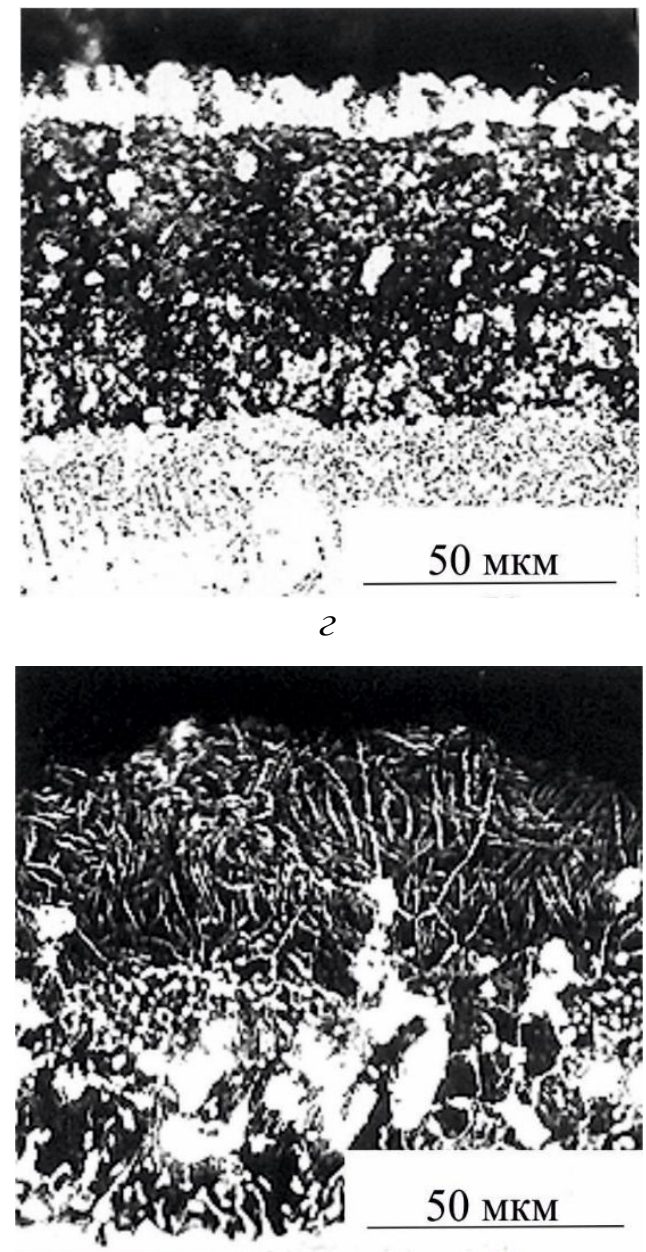

$e$

Рис. 8. Повреждения покрытия состава 20Al-10Si после эксплуатации лопаток вертолетного ГТД: условия эксплуатации: $a-250$ ч; $\sigma$ - один цикл «нагрев - охлаждение» $(20 \leftrightarrow 900){ }^{\circ} \mathrm{C} ; в, 2-1800$ ч; $\partial-150$ ч в морских условиях; $e-6$ ч, $1200{ }^{\circ} \mathrm{C}$ 
Наиболее интенсивно диффузионное «рассасывание» алюмосилицидного слоя происходит в условиях «забросов» температур до $1150-1200^{\circ} \mathrm{C}$. В этом случае кремний способен довольно глубоко проникать под покрытие, связывая хром, титан, ниобий защищаемого жаропрочного сплава в силициды $[7,9]$. Это создает условия для взаимодействия обедненного этими элементами $\gamma$-твердого раствора никеля в защищаемом сплаве с алюминием, в результате образуются зёрна $\beta$-NiAl в сплаве под покрытием на глубине до 100 мкм. При таких высоких температурах кремний может проникать в сплав-основу на глубину более 100 мкм. Следует отметить, что диффузия кремния из покрытия в сплав и связанное с этим образование силицидов тугоплавких элементов, особенно по границам зерен, может привести к разупрочнению сплава и ускоренному механическому разрушению лопаток в процессе эксплуатации.

Испытания на термоциклирование показали несомненное преимущество покрытий 28Al-2Si (табл. 3). Это обусловлено формированием в алюмосилицидном покрытии вместо силицидов $(\mathrm{Cr}, \mathrm{Ti})_{5} \mathrm{Si}_{3}$ соединений кремния, имеющих кристаллическую решётку, близкую решётке $B 2$ алюминида, а именно $\mathrm{Cr}_{3} \mathrm{Si}$ с кубической решёткой (пространственная группа $\mathrm{Pm} 3 \mathrm{n})$. Получение такого силицида в покрытии позволяет, наряду с формированием эффективного диффузионного барьера на границе алюминидного слоя и защищаемого сплава, существенно снизить вероятность образования микротрещин в покрытии.

Таблица 3 - Влияние циклических нагревов на растрескивание покрытий

\begin{tabular}{|c|c|c|c|c|c|c|c|}
\hline \multicolumn{3}{|c|}{$\begin{array}{c}\text { Содержание в покрытии, } \\
\text { мас. } \%\end{array}$} & \multirow[t]{2}{*}{$\begin{array}{c}\text { Сплав } \\
\text { основа }\end{array}$} & \multicolumn{2}{|c|}{$\begin{array}{c}\text { Количество циклов } \\
\text { до появления первой } \\
\text { трещины }\end{array}$} & \multicolumn{2}{|c|}{$\begin{array}{c}\text { Количество трещин на } \\
\text { единицу длины периметра } \\
\text { шлифа после } 25 \text { циклов, } \\
\text { мм }^{-1}\end{array}$} \\
\hline $\mathrm{Al}$ & $\mathrm{Si}$ & B & & $900{ }^{\circ} \mathrm{C}$ & $1100^{\circ} \mathrm{C}$ & $900{ }^{\circ} \mathrm{C}$ & $1100^{\circ} \mathrm{C}$ \\
\hline 35 & - & - & ЖС6У & 1 & 1 & 6,2 & 6,7 \\
\hline $28-30$ & 5 & - & ЖС6У & 5 & 5 & 2,7 & 4,2 \\
\hline $28-30$ & $3-4$ & - & ЧС70 & 7 & 5 & 1,9 & 3,8 \\
\hline $26-28$ & 2 & - & ЖС6У & 8 & 5 & 1,2 & 3,5 \\
\hline $26-28$ & 2 & - & ЧС70 & 10 & 5 & 0,7 & 2,5 \\
\hline $26-28$ & 2 & $1-2$ & ЖС6У & 10 & 5 & 0,5 & 1,9 \\
\hline $26-28$ & 2 & $1-2$ & ЧС70 & 10 & 8 & 0,2 & 1,3 \\
\hline 18 & 10 & - & ЖС6У & 1 & 1 & 6,5 & 8,7 \\
\hline
\end{tabular}

При диффузионном, особенно шликерном, алюмосилицировании нередко отмечаются такие дефекты, как “захват” частиц порошка металлического наполнителя шликера в покрытие или его внутренняя пористость (рис. $9 a$, б). Это безусловно снижает защитные свойства, так как появляется дополнительная возможность для выкрашивания алюмосилицидного слоя скоростным газовым потоком. Качество покрытия определяется равномерностью его толщины и химического состава. В этом смысле крайне нежелательны такие дефекты покрытия, как локальное силицирование, концентрация кремния в светлой поверхностной зоне составляет порядка 40 мас. \% (см. рис. 9 в). Такое покрытие - очень хрупкое и твёрдое (значения микротвердости достигают $1250 \mathrm{HV}$ 0,05), склонно к растрескиванию и выкрашиванию, что существенно снижает его защитные свойства. Локальное силицирование поверхности оказывается возможным при появлении жидкой фазы на поверхности никелевых сплавов (например при использовании смеси на основе порошков ферроалюминия и феррокремния [8]). При температурах выше $920{ }^{\circ} \mathrm{C}$ может происходить спекание смеси и образование на поверхности сплава эвтектик $\mathrm{Ni}_{3} \mathrm{Si}_{2}-\mathrm{NiSi}$ и $\mathrm{NiSi}-\mathrm{NiSi}_{2}$ с температурами плавления 964 и $966{ }^{\circ} \mathrm{C}$ соответственно.

Никелевые сплавы чаще используются в литом состоянии, поэтому дефекты литья

Pugacheva N. B. / Current trends in the development of heat-resistant coatings based on iron, 
open-access journal

могут отразиться на качестве диффузионных покрытий. В частности, это относится к пористости сплава. Покрытия в районе пор наследуют дефектную структуру сплава (рис. 9 г), что выражается в сильной пористости диффузионного слоя и низкой его микротвердости. В результате защитные свойства таких покрытий снижаются.
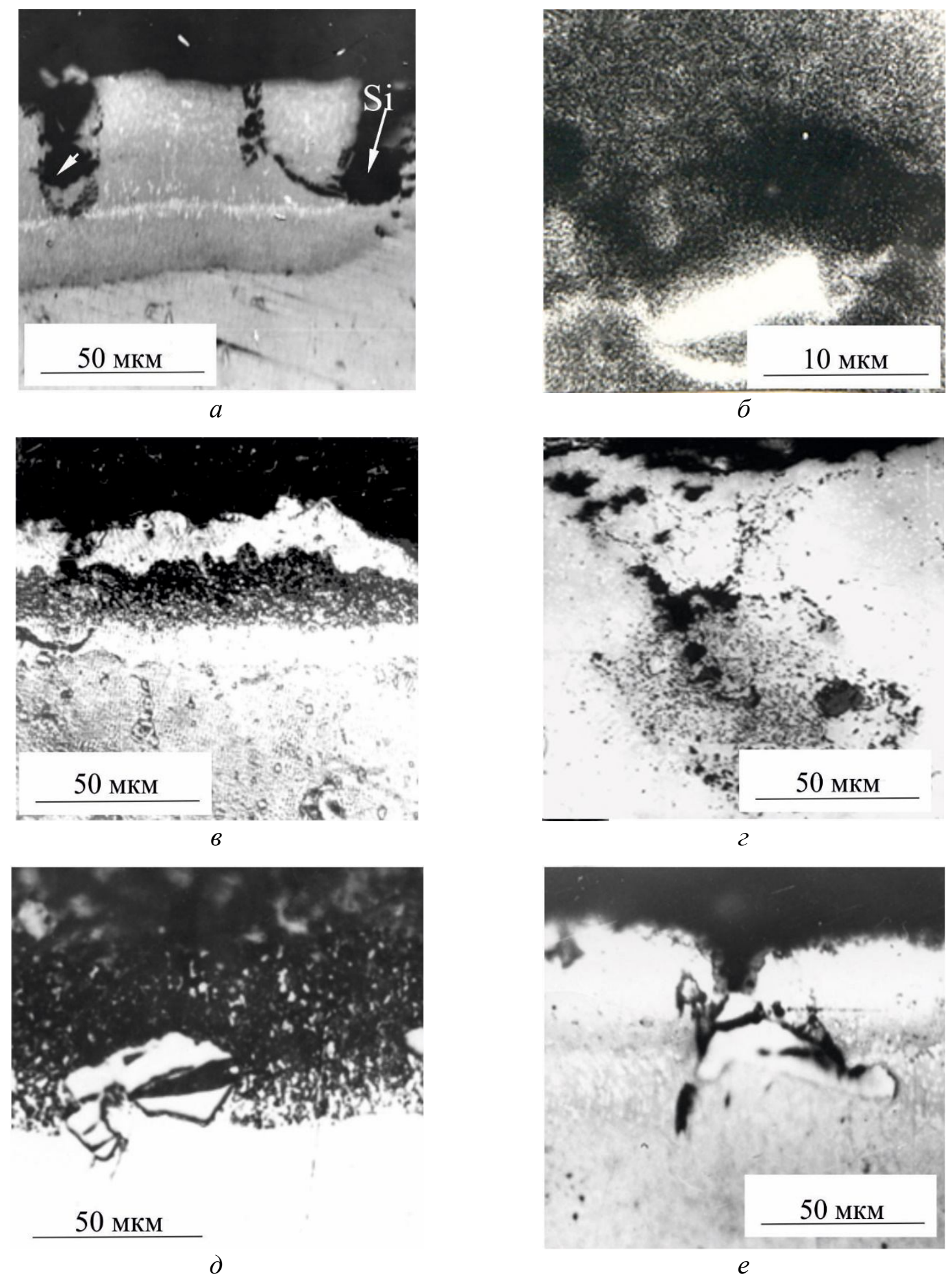

Рис. 9. Дефекты в диффузионных покрытиях на основе $B 2$ интерметаллида NiAl после нанесения: $a, \sigma$ - шликерное покрытие 20Al-10Si ( $\sigma$ - изображение в характеристическом рентгеновском излучении $\mathrm{Si}$ ); в -e - покрытия 30Al-5Si из порошковых смесей средней активности на основе порошков ферросплавов $[2,7]$ 
Имеет значение и размер карбидов в сплаве - основе, причем наибольшее значение имеют карбиды типа МС, так как они образуются в процессе затвердевания сплава и выделяются в виде крупных включений, расположенных произвольно на границах и в объеме зерен. Карбиды МС практически не растворяются при температурах диффузионного насыщения и могут попасть в состав покрытия в неизмененном виде. Помимо объемной доли карбидных выделений большое значение имеют характер их расположения, размеры и морфология. Например, в структуре сплавов ЖС6У и ЖС6К наблюдаются более крупные карбиды, чем в сплавах ЧС70 и ЭП539. Поэтому на первых двух сплавах чаще встречаются связанные с частицами МС дефекты (рис. $9 \partial, e$ ). Крупное карбидное включение может тормозить процесс формирования покрытия (рис. 9 e). Сжимающие напряжения, возникающие при формировании диффузионного слоя, могут вызвать растрескивание карбидного включения (рис. 9 д). Карбиды МС обладают низкой жаро- и коррозионной стойкостью. Поэтому, когда такой карбид расположен у поверхности покрытия, он прежде всего реагирует с агрессивной средой, образуя точечный пробой защитной окисной пленки и инициируя в этом месте коррозию покрытия.

\section{2 Анализ структурных особенностей и защитных свойств напыляемых покрытий}

В отличие от Российских разработок, в зарубежных жаростойких покрытиях в настоящее время не рассматриваются диффузионные методы, которые считаются устаревшими и малоэффективными. Предпочтение отдается напыляемым покрытиям. Составы некоторых зарубежных напыляемых покрытий приведены в табл. 4. Однако при многих преимуществах (независимость от химического состава основы, возможность нанесения покрытий любого заданного состава, повышенная пластичность, технологичность процесса нанесения) эти покрытия имеют свои недостатки и по некоторым показателям уступают получаемыми диффузионными методами.

Прежде всего следует помнить, что все напыляемые покрытия отличаются от диффузионных тем, что их химический и фазовый состав не зависит от состава материала основы. Кроме того, в отличие от диффузионных, напыляемые покрытия всегда двух- и трехфазны. Применительно к жаростойким алюминидным покрытиям, для всех напыляемых покрытий характерно то, что частицы $B 2$ фазы всегда окружены более пластичными твёрдыми растворами. Именно с этим связана повышенная по сравнению с диффузионными покрытиями пластичность. Но в этом скрыты и недостатки напыляемых покрытий, которые более подробно рассмотрим далее.

Механизм осаждения и кристаллизации покрытий при электронно-лучевом напылении обусловливает их столбчатое строение. Зерна фаз, составляющих покрытие, как правило, расположены перпендикулярно поверхности детали, межфазные границы прямые, чаще всего зерно одной фазы имеет длину, равную толщине покрытия. Например, микроструктура электронно-лучевого покрытия системы Co-Cr-Al-Y представляет собой столбчатый двухфазный конгломерат $\beta$-алюминида $\mathrm{CoAl}$ и $\gamma$-твердого раствора хрома в решетке кобальта (рис. 10). На границе сплав - покрытие в результате диффузионного отжига после напыления образуется переходная зона толщиной 20 мкм с содержанием никеля в $\gamma$-фазе около 10 - 15 мас. \%, который поступил за счет диффузии из сплава. В исходном состоянии покрытие имеет толщину 60 - 80 мкм и микротвердость $550-650$ HV 0,05.

Исчерпание защитных свойств всех напыляемых покрытий, в том числе и электроннолучевых, происходит, главным образом, вследствие развития в поверхностных слоях процессов внутреннего окисления и отслаивания покрытия по границе со сплавом-основой (рис. 11). Вытянутость структуры в направлении к поверхности электроннолучевых покрытий, большое количество межфазных границ и наличие многочисленных межкристаллитных микроканалов создают пути облегченной диффузии как алюминия и хрома к поверхности, так и кислорода вглубь покрытия. В связи с этим наряду с образованием окисной пленки развива-

Pugacheva N. B. / Current trends in the development of heat-resistant coatings based on iron, 
ется и внутреннее окисление, в процесс окисления одновременно вовлекается внешний слой покрытия значительной толщины до 10 - 30 мкм (рис. 10 a). Это отражается и на изменении микротвердости слоя, которая снижается до значений $300-400$ HV 0,05.

Таблица 4 - Химический состав жаростойких напыляемых покрытий систем $(\mathrm{Ni}, \mathrm{Co}, \mathrm{Fe})-\mathrm{Cr}-\mathrm{Al}-\mathrm{Y}$, используемых для защиты поверхности деталей из жаропрочных сплавов от ВТО и ВТК [3]

\begin{tabular}{|c|c|c|c|c|c|c|c|}
\hline \multirow{2}{*}{$\begin{array}{c}\text { Марка по- } \\
\text { крытия }\end{array}$} & \multicolumn{7}{|c|}{ Концентрация элементов, мас. \% } \\
\cline { 2 - 8 } & $\mathrm{Ni}$ & Со & $\mathrm{Cr}$ & $\mathrm{Al}$ & $\mathrm{Y}$ & $\begin{array}{c}\text { Другие } \\
\text { элементы }\end{array}$ & $\begin{array}{c}\text { Способ нане- } \\
\text { сения* }\end{array}$ \\
\hline LCO29 & - & Ост. & 18 & 8 & 0,5 & - & ПН1 \\
\hline ADT5 & - & Ост. & 18 & 11 & 0,3 & - & ЭЛИ \\
\hline LCO5 & - & Ост. & 19 & 10 & 0,5 & - & ПН1 \\
\hline ADT2 & - & Ост. & 23 & 12 & 0,3 & - & ЭЛИ \\
\hline LCO7 & - & Ост. & 23 & 13 & 0,6 & - & ПН1 \\
\hline ADT14 & - & Ост. & 30 & 5 & 0,5 & - & ЭЛИ \\
\hline Amdry 961 & Ост. & - & 17 & 6 & 0,5 & - & ПН2 \\
\hline Amdry 962 & Ост. & - & 22 & 10 & 1 & - & ПН2 \\
\hline ADT16 & Ост. & - & 25 & 12 & 0,3 & - & ЭЛИ \\
\hline Amdry 963 & Ост. & - & 25 & 5 & 0,4 & - & ПН2 \\
\hline ADT1 & Ост. & - & 38 & 11 & 0,3 & - & ЭЛИ \\
\hline ADT7 & Ост. & 22 & 18 & 12 & 0,3 & - & ЭЛИ \\
\hline ADT9 & Ост. & 20 & 42 & 5 & 0,3 & - & ЭЛИ \\
\hline LN21 & Ост. & 22 & 21 & 7,5 & 0,5 & - & ПН1 \\
\hline Amdry 995 & Ост. & 23 & 20 & 8,5 & 0,6 & Та 4 & ПН2 \\
\hline LN34 & Ост. & 0,5 & 20 & 11 & 0,5 & Мо 0,5 & ПН1 \\
\hline LCO22 & 32 & Ост. & 21 & 7,5 & 0,5 & - & ПН1 \\
\hline Amdry 996 & 10 & Ост. & 25 & 7 & 0,6 & Та 5 & ПН2 \\
\hline LCO37 & 23 & Ост. & 30 & 3 & 0,5 & - & ПН1 \\
\hline
\end{tabular}

*ПН1 - плазменное напыление в атмосфере аргона; ПН2 - плазменное напыление в динамическом вакууме; ЭЛИ - электронно-лучевое испарение.

Одним из недостатков напыляемых покрытий является интенсивное диффузионное взаимодействие со сплавом-основой при температуре эксплуатации. После 840-часовой эксплуатации толщина покрытия вырастает до 150 - 180 мкм, причем примерно в 2 раза увеличивается толщина диффузионной зоны на границе со сплавом, а содержание никеля в ней достигает до 30 - 40 мас. \%. Появление за счет нескомпенсированной диффузии микропор, развитие внутреннего окисления с образованием дисперсных окислов, окислительное раскрытие микроканалов (рис. 11 в) резко ослабляют механическую прочность поверхностного слоя покрытия. На определенном этапе воздействия скоростного газового потока в поверхностном слое возникают продольные трещины и он отслаивается. После скалывания металло-оксидного обедненного слоя в процесс окисления вовлекается новый слой покрытия практически исходного состава. В результате происходит послойное разрушение покрытия и его работоспособность определяется как химическим составом и структурой, так и толщиной. Такой механизм повреждения характерен для напыляемых покрытий и не позволяет в полной мере реализовать запас долговечности, заложенный при разработке жаростойкой композиции. 
onen-2CCess journal



$a$

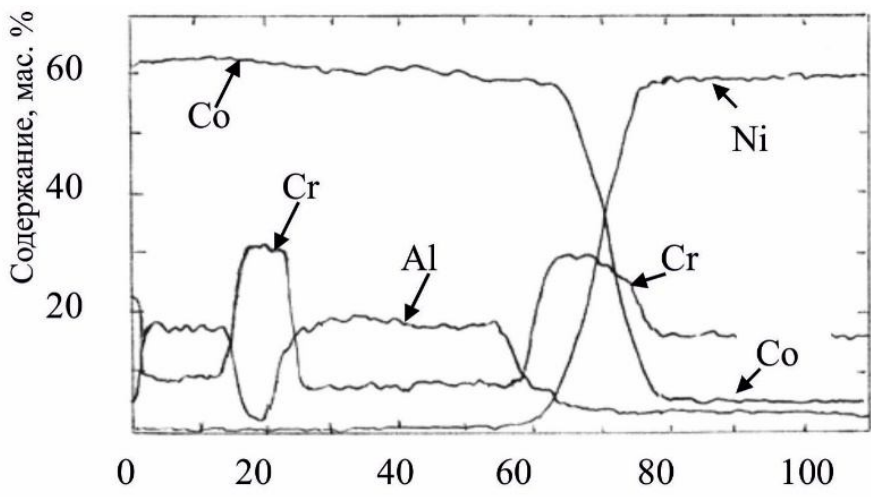

Расстояние от поверхности, мкм

б

Рис. 10. Микроструктура и распределение элементов в электронно-лучевом покрытии Co-Cr-Al-Y на никелевом сплаве: $a$ - микроструктура покрытия;

$\sigma$ - распределение элементов по толщине покрытия

Несмотря на то, что способность $\gamma$-твердого раствора в электронно-лучевом покрытии пластически деформироваться должна обеспечивать более высокую стойкость к растрескиванию по сравнению с диффузионными алюминидными покрытиями, состоящими из B2фазы и силицидов $\mathrm{M}_{5} \mathrm{Si}_{3}$, довольно часто после эксплуатации наблюдаются трещины (рис. 11 2). Причиной их возникновения являются существенные различия значений к.т.р. для $\gamma$ твёрдого раствора и интерметаллида [6]. Зарождающаяся при термоциклировании на межфазной границе микротрещина быстро растёт вдоль вытянутого $\beta$-зерна. Заметно снизить склонность покрытий к растрескиванию удаётся за счёт измельчения микроструктуры, например при атомно-ионном распылении. Однако такие недостатки, как низкая адгезия покрытия к сплаву-основе, образование дефектов нанесения, сохраняются (рис. $11 \partial, e$ ). При температурах $700-900{ }^{\circ} \mathrm{C}$ происходит обеднение поверхностного слоя покрытия алюминием, как и в случае электронно-лучевых покрытий. После испытаний на термоциклирование трещины образуются на дефектах нанесения и в обеднённом поверхностном слое (рис. $11 e$ ). 
open-access journal
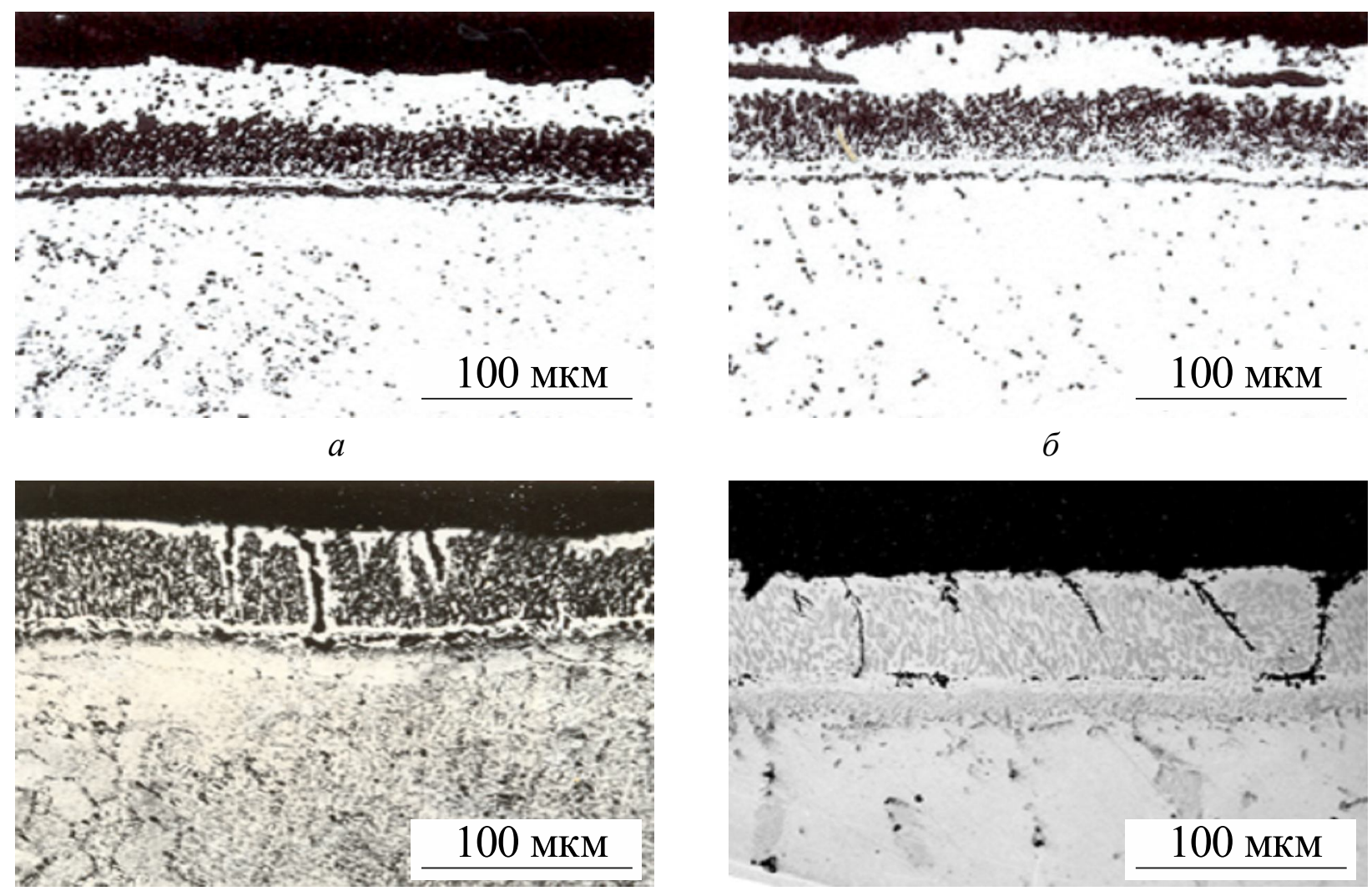

$\sigma$

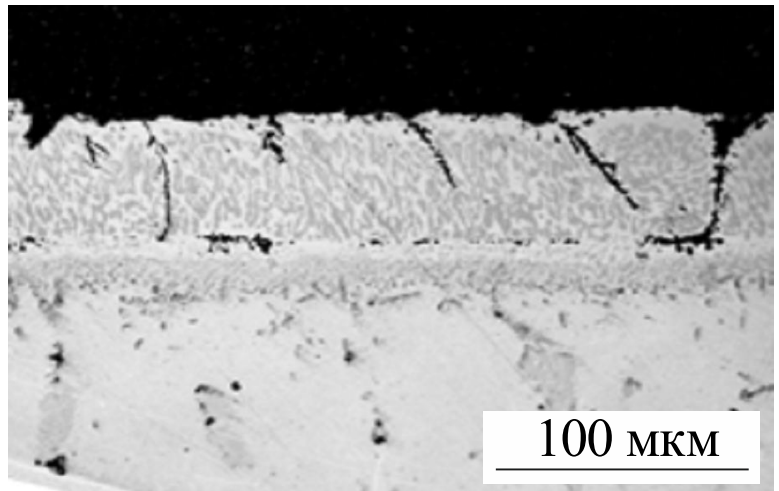

2
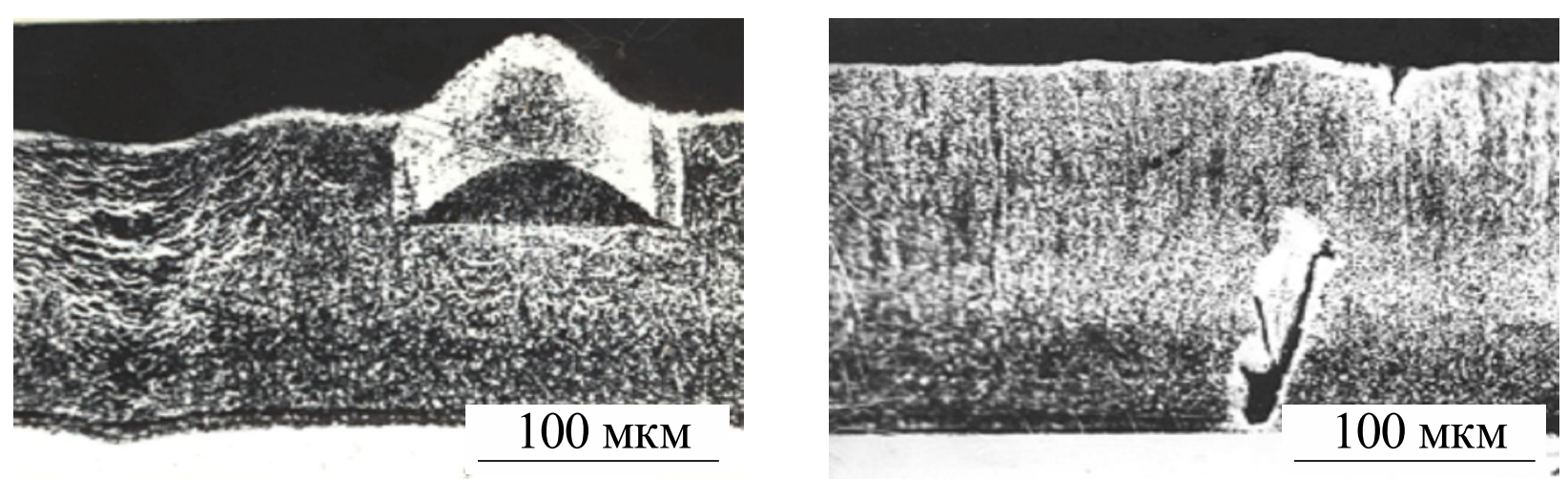

$\partial$

$e$

Рис. 11. Повреждения напыляемых покрытий при их нанесении и после эксплуатации: $a-2$ - электроннолучевое покрытие 70Co3 Ni17Cr9AlY после 840-часовой эксплуатации судового двигателя; $\partial, e$ - покрытие 67Co20Cr12AlY, нанесенное атомно-ионным распылением: $\partial$ - исходное покрытие; $e$ - термоциклирование $(20 \leftrightarrow 920){ }^{\circ} \mathrm{C}$,

охлаждение в воде, 5 - циклов

Таким образом, жаростойкие напыляемые покрытия системы (Ni,Co)-Cr-Al-Y, обладют уникальным сочетанием хорошей пластичности и термостойкости металлической композиции и высоких защитных свойств окисной пленки. Легкость варьирования состава напыляемых покрытий позволяет выбирать наиболее эффективный вариант для конкретных условий эксплуатации. В частности, для работы в условиях высокотемпературной окислительной среды преимущество имеют покрытия на никелевой основе с повышенным содержанием алюминия; в коррозионно-активной среде более долговечны покрытия на кобальтовой основе с повышенным содержанием хрома. За рубежом покрытия наносят в серийном производстве следующие фирмы: General Electric (США), Siemens (Германия), Hitachi (Япо-

Pugacheva N. B. / Current trends in the development of heat-resistant coatings based on iron, 
ния), Castolin Eutectic (Япония), Avesta Welding (Германия), Carbo Weld (Германия), Interstahl Servce Gmbh (Германия). В России серийное производство осуществляют: ВИАМ (Москва), ООО "ТУРБОМЕТ" (Екатеринбург), ОАО "Авиадвигатель" - "Пермские моторы" (Пермь).

Тем не менее многочисленные исследования показали, что долговечность напыляемых покрытий ограничена недостаточным запасом алюминия, которого не хватает для постоянного длительного восстановления скалывающейся при эксплуатации защитной оксидной пленки $\mathrm{Al}_{2} \mathrm{O}_{3}$. Исчерпание защитных свойств происходит послойно так, что долговечность напыляемых покрытий во многом определяется их толщиной. Отрицательным свойством напыляемых покрытий является их низкая диффузионная стабильность: при рабочих температурах покрытия интенсивно взаимодействуют с основой, поскольку на границе нет защитного диффузионного барьера, как в диффузионных покрытиях, а химический состав поверхностного слоя существенно отличается от состава основы, обеспечивая тем самым движущую силу диффузии.

Кроме того, как показывает технологический опыт нанесения жаростойких покрытий, современные технологичные методы напыления не позволяют полностью исключить формирование дефектов различного типа, причем их виды и причины появления гораздо разнообразнее, чем в случае диффузионных методов.

\section{3 Многослойные жсаростойкие покрытия}

Качественным скачком в развитии жаростойких напыляемых покрытий стал переход от металлических покрытий $(\mathrm{Ni}, \mathrm{Co}) \mathrm{CrAlY}$ к двухслойным металлокерамическим теплозащитным покрытиям (Ni,Co) $\mathrm{CrAlY} / \mathrm{ZrO}_{2}\left(\mathrm{Y}_{2} \mathrm{O}_{3}\right)$, в которых основную тепловую, коррозионную и эрозионную нагрузку принимает на себя внешний керамический слой толщиной 60-125 мкм, а традиционное металлическое покрытие играет роль промежуточного слоя, обеспечивающего хорошее сцепление керамики с защищаемой поверхностью, а также дополнительную защиту от проникновения кислорода и серы в жаропрочный сплав $[15,16,18]$. Такие покрытия имеют явные преимущества перед однослойными не только в высоко теплонагруженных авиационных турбинах, но и в относительно низкотемпературных промышленных турбинах. Серийное производство в России проводят ВИАМ (Москва), ООО "ТУРБОМЕТ" (Екатеринбург), ОАО "Авиадвигатель" - "Пермские моторы" (Пермь), а за рубежом - General Electric (США), Siemens (Германия), Hitachi (Япония), Castolin Eutectic (Япония), Avesta Welding (Германия), Carbo Weld (Германия), Interstahl Servce Gmbh (Германия). На рис. 12 приведены микроструктуры многослойных жаростойких покрытий для защиты поверхности лопаток ГТУ из жаропрочных никелевых сплавов, разработанных и наносимых в Всероссийском институте авиационных материалов (ВИАМ). Основная проблема теплозащитных покрытий - ограниченная термостойкость керамического слоя, поэтому часто успешное применение такого покрытия зависит от правильного выбора оптимального состава и структурного состояния металлического подслоя.
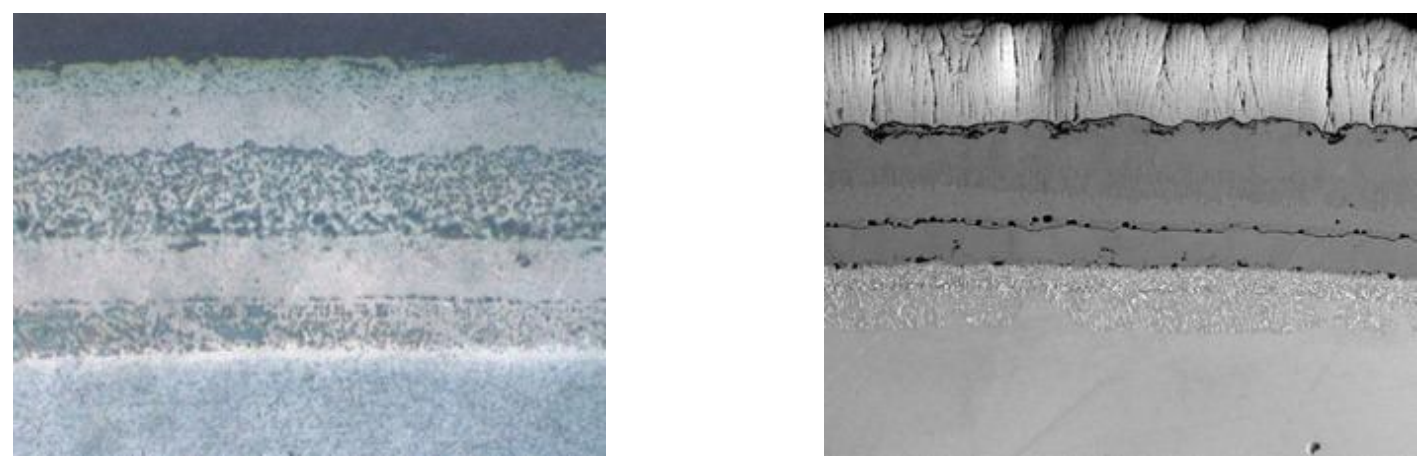

Рис. 12. Микроструктура многослойных жаростойких покрытий для защиты поверхности лопаток ГТУ из жаропрочных никелевых сплавов - разработка ВИАМ, х 500

Pugacheva N. B. / Current trends in the development of heat-resistant coatings based on iron, 
Нами были проведены исследования защитных свойств трехслойных покрытий, второй и третий слой которых наносили атомно-ионным распылением (АИР) в Харьковском физико-техническом Институте академии наук Украины. Свойства каждого из слоев приведены в табл. 5. В технологии АИР за счет электромагнитного высокочастотного поля ионизируется приблизительно 10 - 20 \% парового потока. Причем процентное содержание ионизированных атомов различных элементов в потоке не одинаково: прямо пропорционально содержанию данного элемента в паровом потоке и обратно пропорционально потенциалу ионизации атомов (чем меньше потенциал ионизации, тем больше атомов будет находиться в паровом потоке в виде заряженных ионов). Первые потенциалы ионизации атомов испарения элементов имеют следующие значения: $\mathrm{Co}-7,8$ эВ; $\mathrm{Cr}-6,7$ эВ; $\mathrm{Y}-6,6$ эВ; $\mathrm{Al}-5,94$ эВ. В паровом потоке ионов алюминия будет больше, чем кобальта, хрома и иттрия. Этим объясняется склонность АИР-покрытий к слоистости микроструктуры (рис. 11 )). Вблизи сплаваосновы образуется слой обогащенный алюминием ( $\beta$-фаза CoAl), далее - слои фазы $B 2$ с меньшим содержанием алюминия.

Отжиг комбинированного покрытия с АИР-слоями непосредственно после напыления имеет такие же цели, как и для электронно-лучевых или плазменных покрытий, а именно улучшение адгезии слоя к подложке за счет образования диффузионной зоны толщиной $3-5$ мкм, и выравнивание химического состава покрытия по толщине. При нанесении на слой термодиффузионного алюмосилицидного покрытия, закономерности формирования АИРпокрытия не изменились: отжиг $1020^{\circ} \mathrm{C}, 2$ ч. приводит к получению хорошей адгезии слоев и формированию диффузионной зоны между ними, даже с внешним керамическим слоем (рис. 13 a). Следует отметить, что существенные отличия по содержанию алюминия в сплаве-подложке, термодиффузионном и АИР-слоях (см. табл. 5) приводят к диффузионному перераспределению алюминия в двух противоположных направлениях: как в сплав-основу, так и во второй АИР-слой. Потеря алюминия за счет диффузии его в сплав при обычных температурах эксплуатации настолько мала, что этот процесс обычно не учитывается.

Таблица 5 - Параметры комбинированного покрытия с АИР-слоями (сплав ЭП539)

\begin{tabular}{|c|c|c|c|c|c|c|c|}
\hline \multirow{2}{*}{$\begin{array}{c}\text { № } \\
\text { слоя }\end{array}$} & \multirow{2}{*}{ Состав } & \multicolumn{4}{|c|}{$\begin{array}{c}\text { Содержание основных элементов, } \\
\text { мас. \% }\end{array}$} & \multirow{2}{*}{$\begin{array}{l}\text { Толщина } \\
\text { слоя, мкм }\end{array}$} & \multirow{2}{*}{$\begin{array}{c}\mathrm{HV}_{0,05} \\
\text { МПа }\end{array}$} \\
\hline & & $\mathrm{Ni}$ & Co & $\mathrm{Cr}$ & $\mathrm{Al}$ & & \\
\hline 1 & $\begin{array}{l}\text { Диффузионный } \\
\text { 28Al-2Si-(Ce,La) }\end{array}$ & $50-52$ & $2-3$ & $10-12$ & $26-28$ & $40-45$ & 7600 \\
\hline 2 & $\begin{array}{l}\text { Ni Co-Cr-Al } \\
\text { АИР } \\
\end{array}$ & $25-28$ & $38-41$ & 28 & 4 & $60-65$ & 5600 \\
\hline 3 & $\begin{array}{l}\mathrm{ZrO}_{2}, \mathrm{Y}_{2} \mathrm{O}_{3} \\
\mathrm{~A} И \mathrm{P}\end{array}$ & $\mathrm{Zr}-65$ & $Y-8$ & - & - & $15-20$ & 9600 \\
\hline
\end{tabular}

Испытания на жаро-, коррозионную и термостойкость показали, что наиболее слабыми участками, как и при плазменном напылении, являются границы между слоями. По сравнению с нанесенными плазменным распылением, АИР-слои имеют более однородное, плотное строение и в меньшей степени подвержены окислению. Поэтому показатели жаро- и коррозионной стойкости композиций с АИР-слоями выше по сравнению с напылёнными плазмой слоями, как будет показано далее.

Испытания на термостойкость наглядно иллюстрируют, каким образом недостатки одного слоя компенсируются за счет других слоев. При достаточно большой толщине слоев в композиции (см. табл. 5) первые термоусталостные трещины появляются в диффузионном слое после 5 циклов нагрев охлаждение в воду по режиму $(25 \leftrightarrow 950){ }^{\circ} \mathrm{C}$. Эти трещины гасятся в пластичном АИР-слое, и с увеличением количества циклов не растут (рис. 13 б). При регулировании толщины слоев в композиции можно подобрать оптимальные с точки зрения 
open-access journal

зарождения темоусталостных трещин. Например, при толщине термодиффузионного слоя не более 30 мкм термоусталостные трещины не появляются, поскольку возникающие термические напряжения релаксируют за счет пластической деформации сплава-основы и АИР-слоя.
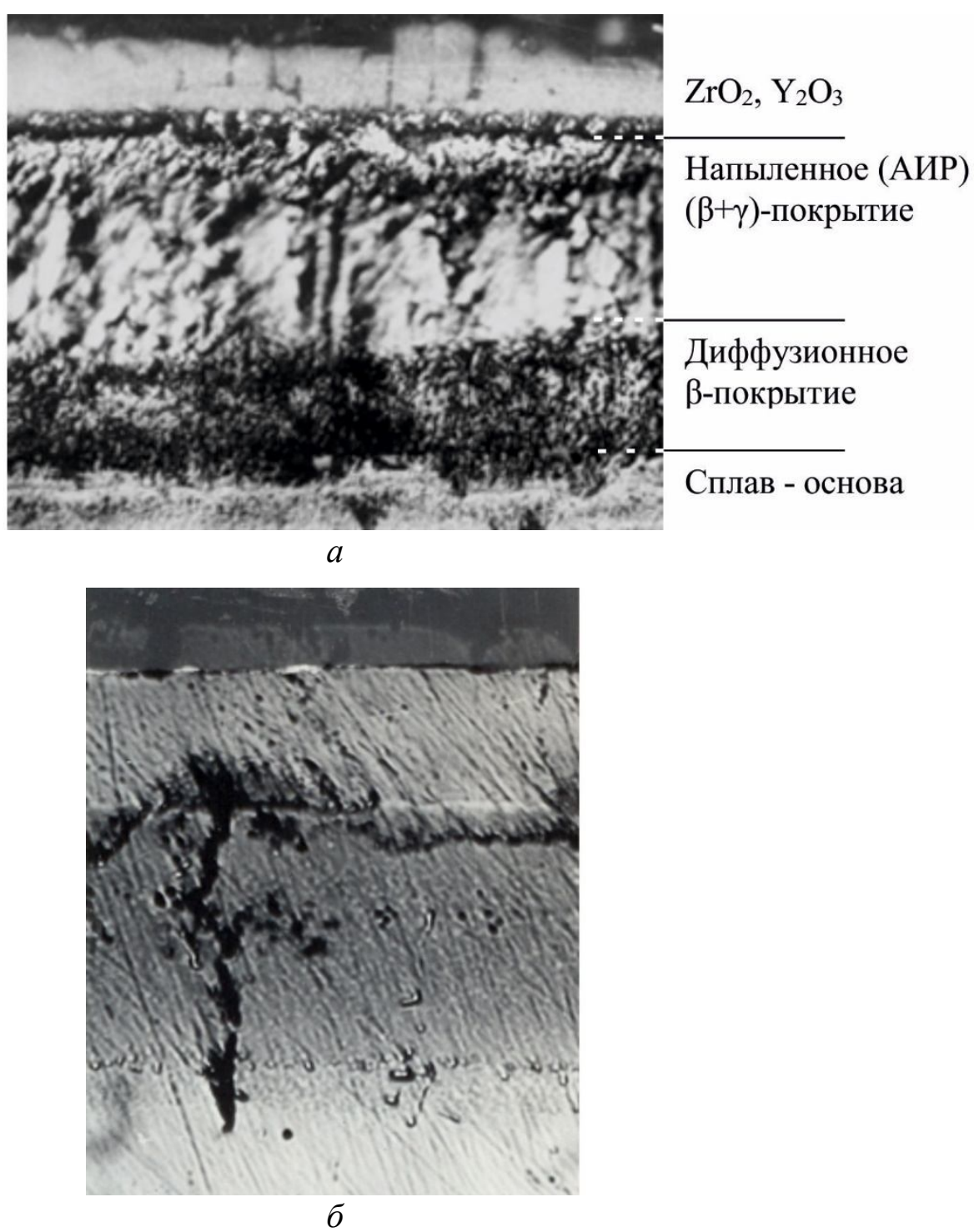

Рис. 13. Микроструктура комбинированного терможаростойкого покрытия: $a$ - исходное состояние; $\sigma$ - после 25 циклов $950{ }^{\circ} \mathrm{C}(15$ мин. $) \leftrightarrow 20^{\circ} \mathrm{C}$ с охлаждением в воде

Были исследованы также комбинированные покрытия [16], полученные при различных последовательностях нанесения термодиффузионного алюминидного (ДП), плазменного интерметаллидного (ПМ), плазменного керамического слоев (ПК), а также при лазерном оплавлении двухслойного покрытия, состоящего из алюминидного термодиффузионного слоя Al-Si-P3М и плазменного слоя Ni-Cr-Al-Y. Покрытия наносили на никелевый сплав ЭИ929, широко используемый для изготовления лопаток стационарных газовых турбин. Параметры покрытий приведены в табл. 6, а микроструктура и распределение элементов по толщине слоя - на рис. 14.

В исходном состоянии комбинированное покрытие состоит из трех слоев. Первый слой 28Al-2Si-1P3М толщиной 40-55 мкм расположен на границе со сплавом-основой. Этот слой обеспечивает высокую жаро- и коррозионную стойкость, а также диффузионную стабильность всего покрытия в целом, т.е. эффективно препятствуют диффузионному перераспределению никеля в защитное покрытие при высоких температурах. Второй - плазменный

Pugacheva N. B. / Current trends in the development of heat-resistant coatings based on iron, 
слой Ni-Cr-Al-Y толщиной 115 мкм - состоит из $\beta$-алюминида NiAl и твердого раствора $\mathrm{Cr}$ в $\gamma$-Ni. Этот слой обеспечивает высокую термостойкость покрытия, а также хорошую адгезию керамического внешнего слоя к поверхности. Третий - внешний керамический слой $\left(\mathrm{ZrO}_{2}, \mathrm{Y}_{2} \mathrm{O}_{3}\right)$ толщиной около 50 мкм - является теплозащитным, т.е. снижает температуру поверхности сплава ЭИ929 в процессе эксплуатации.

После нанесения покрытия на границе первого и второго слоев обнаружены мелкие единичные поры, заполненные окислами $\mathrm{M}_{2} \mathrm{O}_{3}$, содержащими 60 мас. \% $\mathrm{Cr}$, около 5 мас. \% Al и примерно 1 мас. \% Y. Для повышения адгезии всех трех слоев комбинированного покрытия был проведён отжиг в вакууме при $1050{ }^{\circ} \mathrm{C}$ в течение 2 ч. После этого произошло залечивание микропор, а также некоторое выравнивание химического состава в металлических слоях, особенно по алюминию (см. табл. 6).

Для повышения коррозионной стойкости плазменного слоя $\mathrm{Ni}-\mathrm{Cr}-\mathrm{Al}-\mathrm{Y}$ и уменьшения микропористости было проведено термодиффузионное алюмосилицирование с получением поверхностного слоя (см. рис. 4). При этом происходит увеличение содержания алюминия в приповерхностной зоне плазменного слоя на глубине 50-60 мкм в 1,5-2 раза (см. табл. 6) и формируется более плотный слой без видимых при металлографическом анализе пор. Толщина первоначально напыленного плазменного слоя Ni-Cr-Al-Y не изменилась.

Лазерный переплав двухслойного покрытия, состоящего из ДП и ПМ, устраняет обычную неоднородность структуры плазменного покрытия и приводит к формированию плотного беспористого защитного слоя с однородной мелкодисперсной структурой и равномерным распределением легирующих элементов. Значения микротвердости составляют 680-720 МПа. Фазовый состав образовавшегося в результате лазерной обработки поверхностного слоя следующий: $\gamma$-твердый раствор на основе никеля, $\gamma^{\prime}$-фаза $\mathrm{Ni}_{3} \mathrm{Al}$ и $\alpha$-твердый раствор на основе Cr. Сплав-основа участвует в лазерном переплаве поверхности наряду с ДП, поэтому содержание алюминия в покрытии по сравнению с ПМ практически не меняется (см. табл. 6). Особо следует отметить состояние границы раздела между ДП и ПМ. Если в случае последовательного нанесения этих слоев наблюдается пористость на границе между слоями, то после лазерного оплавления такой границы не существует.

Кинетика окисления на воздухе при температуре $950{ }^{\circ} \mathrm{C}$ трехслойного покрытия без отжига и с отжигом в вакууме практически одинакова (рис. 15). Поскольку керамический внешний слой имеет пористое строение, он легко пропускает кислород к металлическому слою. Второй слой Ni-Cr-Al-Y имеет также характерное для плазменных покрытий пористое строение. Очевидно, в первые часы выдержки при температуре $950{ }^{\circ} \mathrm{C}$ на воздухе происходит внутреннее окисление второго слоя, сопровождающееся образованием окислов $\mathrm{Al}_{2} \mathrm{O}_{3}$ и $\mathrm{Cr}_{2} \mathrm{O}_{3}$ во всем объеме ПМ. Этим и объясняется увеличение веса образцов с трехслойным покрытием в первые часы испытаний на жаростойкость. В дальнейшем происходит торможение процесса окисления. Скорость окисления, о которой можно судить по углу наклона линейной зависимости удельного привеса образцов от длительности испытания (линии 5 и 6 на рис. 15), сохраняется на уровне ДП (линии 1 и 3 на рис. 15). 
open-access journal
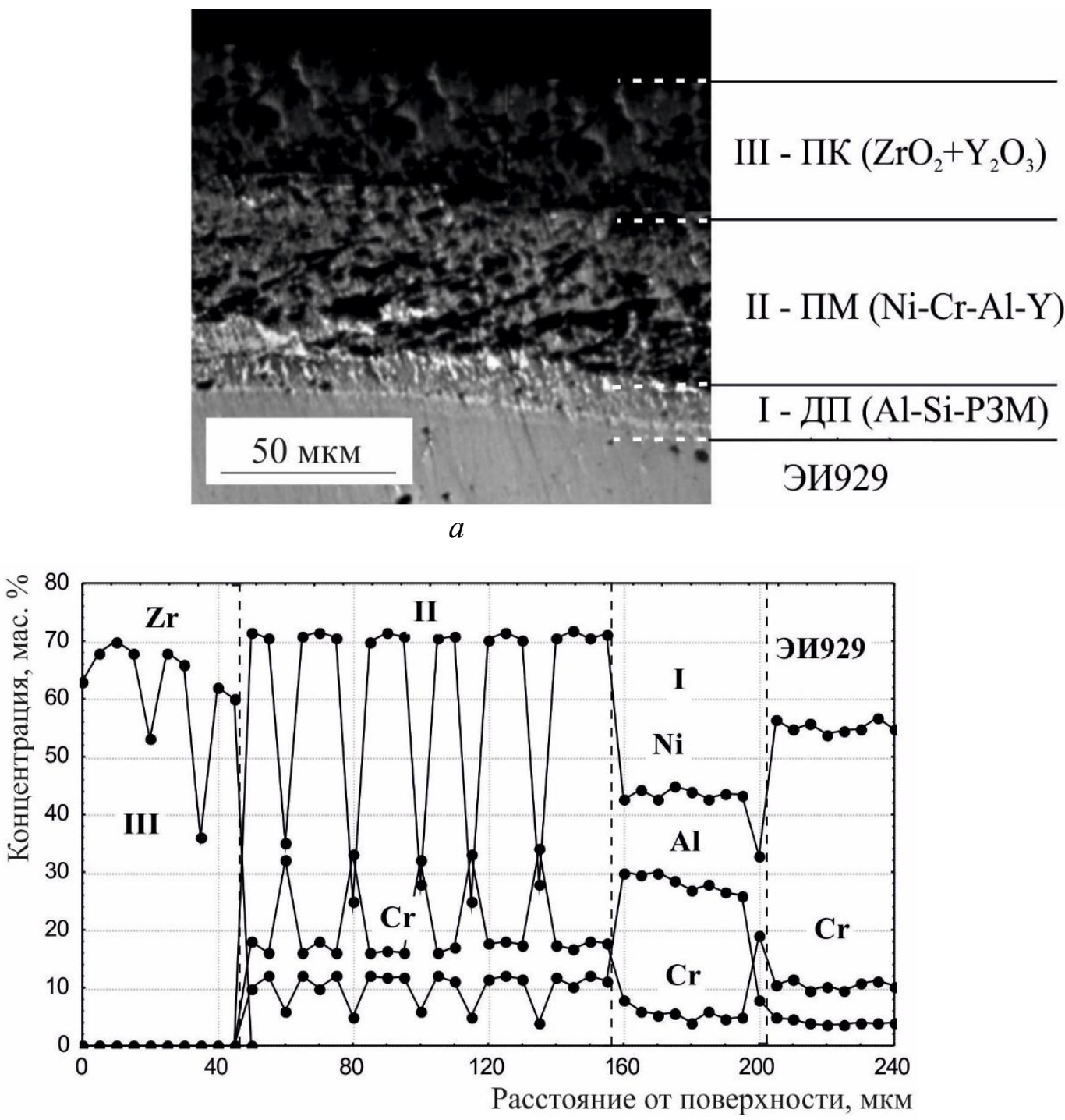

$\sigma$

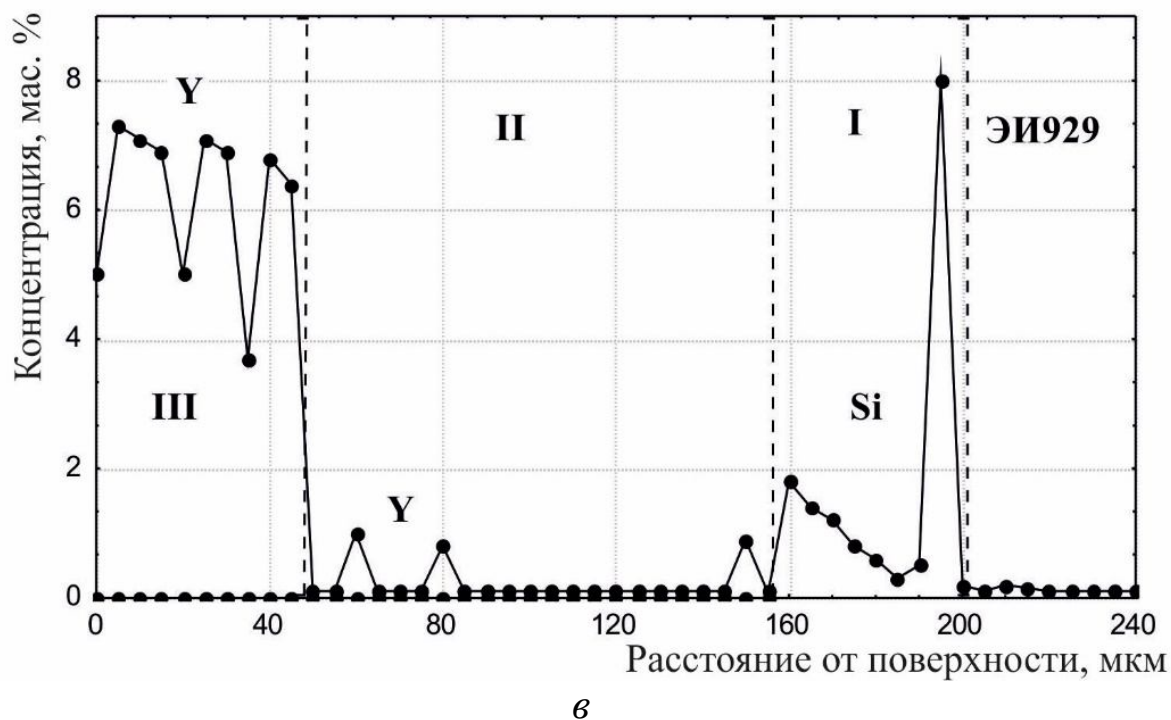

Рис. 14. Микроструктура (a) и распределение элементов $(\sigma, \varepsilon)$ в комбинированном покрытии на никелевом сплаве ЭИ929

Pugacheva N. B. / Current trends in the development of heat-resistant coatings based on iron, nickel and cobalt aluminides 
После 515-часовой выдержки на воздухе при температуре $950{ }^{\circ} \mathrm{C}$ трехслойное покрытие сохранилось полностью на поверхности образцов (табл. 7). Отслоений керамического внешнего слоя не наблюдалось. В покрытии, в целом, уменьшилось содержание алюминия и хрома, который расходовался на образование защитных окислов. Однако это не привело к образованию алюминида $\gamma^{\prime}-\mathrm{Ni}_{3} \mathrm{Al}$. Во внешней зоне второго слоя зафиксировано присутствие окисла $\mathrm{Y}_{2} \mathrm{O}_{3}$. На границе между ДП и ПМ присутствуют микропоры, заполненные окислами хрома, алюминия и иттрия. При коагуляции этих микропор могут образовываться длинные цепочки пустот, что неизбежно приведет к скалыванию и осыпанию плазменных слоев при более длительных испытаниях.

При нанесении керамического слоя на ДП образуется композиция с недостаточной прочностью сцепления керамического и металлического слоев. Даже при небольших нагрузках происходят, как и следовало ожидать, локальные сколы керамического слоя. Однако при испытаниях жаростойкости это покрытие показало достаточно высокие защитные свойства. Очевидно, процесс окисления этого двухслойного покрытия на воздухе определяется защитными свойствами металлического слоя алюминидов никеля, легированных кремнием и P3M.

Таблица 6 - Параметры трёхслойных комбинированных покрытий в исходном состоянии

\begin{tabular}{|c|c|c|c|c|c|c|c|c|c|}
\hline \multirow{2}{*}{$\begin{array}{l}\text { № } \\
\text { п/п }\end{array}$} & \multirow{2}{*}{$\begin{array}{c}\text { Тип покры- } \\
\text { тия }\end{array}$} & \multirow[t]{2}{*}{ Вид слоя } & \multirow{2}{*}{$\begin{array}{c}\text { Толщи- } \\
\text { на слоя, } \\
\text { мкм. }\end{array}$} & \multicolumn{6}{|c|}{$\begin{array}{c}\text { Содержание элементов, } \\
\text { мас. } \%\end{array}$} \\
\hline & & & & $\mathrm{Cr}$ & $\mathrm{Al}$ & $\mathrm{Ni}$ & $\mathrm{Si}$ & $\mathrm{Zr}$ & $\mathrm{Y}$ \\
\hline \multirow{2}{*}{1} & \multirow{2}{*}{ ДП+ ПК } & Al-Si-P3M & $40-55$ & $6-8$ & $26-30$ & $47-52$ & $1-2$ & - & \\
\hline & & $\mathrm{ZrO}_{2}+8 \mathrm{Y}_{2} \mathrm{O}_{3}$ & $50-60$ & - & - & - & - & $65-70$ & $6-7$ \\
\hline \multirow[b]{2}{*}{2} & \multirow[b]{2}{*}{ дП + ПМ } & Al-Si-P3M & $40-55$ & $6-8$ & $26-28$ & $47-52$ & $1-2$ & - & - \\
\hline & & Ni-Cr-Al-Y & $110-120$ & $\begin{array}{c}\gamma: 29-31 \\
\beta: 9-11\end{array}$ & $\begin{array}{c}\gamma: 4-6 \\
\beta: 18-20\end{array}$ & $\begin{array}{l}\gamma: 63-65 \\
\beta: 70-72\end{array}$ & - & - & - \\
\hline 3 & $\begin{array}{c}\text { ДП + ПМ + } \\
\text { лазерная } \\
\text { обработка }\end{array}$ & Ni-Cr-Al-Y & 150 & $9-11$ & $11-13$ & $65-69$ & $<1$ & - & $<1$ \\
\hline \multirow[t]{2}{*}{4} & \multirow[t]{2}{*}{ ПМ + ДП } & Ni-Cr-Al-Y & 60 & $\begin{array}{c}\gamma: 29-31 \\
\beta: 9-11\end{array}$ & $\begin{array}{c}\gamma: 4-6 \\
\beta: 18-20\end{array}$ & $\begin{array}{l}\gamma: 63-65 \\
\beta: 70-72\end{array}$ & - & - & $<1$ \\
\hline & & Al-Si-P3M & $50-60$ & $6-8$ & $26-30$ & $47-52$ & $1-2$ & - & - \\
\hline \multirow{3}{*}{5} & \multirow{3}{*}{$\begin{array}{c}\text { ДП + ПМ + } \\
\text { ПК }\end{array}$} & Al-Si-P3M & $40-55$ & $6-8$ & $26-30$ & $47-52$ & $1-2$ & - & - \\
\hline & & Ni-Cr-Al-Y & $110-120$ & $\begin{array}{c}\gamma: 29-31 \\
\beta: 9-11\end{array}$ & $\begin{array}{c}\gamma: 4-6 \\
\beta: 18-20\end{array}$ & $\begin{array}{l}\gamma: 63-65 \\
\beta: 70-72\end{array}$ & - & - & $<1$ \\
\hline & & $\mathrm{ZrO}_{2}+8 \mathrm{Y}_{2} \mathrm{O}_{3}$ & 50 & - & - & - & - & $65-70$ & $6-7$ \\
\hline \multirow[b]{3}{*}{6} & \multirow{3}{*}{$\begin{array}{c}\text { ДП + ПМ } \\
\text { ПК + отжиг } \\
\text { в вакууме } \\
1050^{\circ} \mathrm{C}, \\
2 \text { ч. }\end{array}$} & Al-Si-P3M & $50-60$ & $6-9$ & $22-25$ & $47-52$ & $1-2$ & - & \\
\hline & & Ni-Cr-Al-Y & 120 & $\begin{array}{c}\gamma: 27-29 \\
\beta: 9-11\end{array}$ & $\begin{array}{c}\gamma: 6-8 \\
\beta: 16-18\end{array}$ & $\begin{array}{l}\gamma: 63-65 \\
\beta: 72-75\end{array}$ & - & - & $<1$ \\
\hline & & $\mathrm{ZrO}_{2}+8 \mathrm{Y}_{2} \mathrm{O}_{3}$ & 50 & - & - & $60-66$ & & $60-66$ & $5-7$ \\
\hline
\end{tabular}

В случае двухслойного покрытия ДП + ПМ уже после 228-часовой выдержки наблюдали появление осыпи в тиглях (образцы в ходе испытаний взвешивали в тиглях вместе с осыпью). Увеличение содержания алюминия в ПМ за счет термодиффузионного алитирования не привело к ожидаемому повышению защитных свойств. Уже после 16-часовой выдержки на воздухе при $950{ }^{\circ} \mathrm{C}$ произошло интенсивное отшелушивание и отслаивание покрытия, сопровождающееся резким увеличением массы образцов.

Pugacheva N. B. / Current trends in the development of heat-resistant coatings based on iron, 




Рис. 15. Кинетика окисления сплава ЭИ929 с покрытиями при температуре $950{ }^{\circ} \mathrm{C}$ :

1 - ДП + ПК; 2 - ДП + ПМ; 3 - ДП (приведено для сравнения); 4 - ПМ + ДП;

5 - ДП + ПМ + ПК; 6 - ДП + ПМ + ПК + отжиг в вакууме $1050{ }^{\circ} \mathrm{C} ; 7$ - без покрытия

В случае двухслойного покрытия ДП + ПМ уже после 228-часовой выдержки наблюдали появление осыпи в тиглях (образцы в ходе испытаний взвешивали в тиглях вместе с осыпью). Увеличение содержания алюминия в ПМ за счет термодиффузионного алитирования не привело к ожидаемому повышению защитных свойств. Уже после 16-часовой выдержки на воздухе при $950{ }^{\circ} \mathrm{C}$ произошло интенсивное отшелушивание и отслаивание покрытия, сопровождающееся резким увеличением массы образцов.

В случае лазерного проплавления диффузионного алюминидного слоя совместно с плазменной композицией Ni-Cr-Al-Y не имело смысла взвешивание образцов в ходе испытаний, поскольку ширина дорожки оплавления составляла всего 2 мм, а остальная поверхность образца остается покрытой плазменным слоем. Привесы этих образцов мало отличаются от привесов двухслойного покрытия (ДП + ПМ), поэтому сравнительную жаростойкость оплавленного лазерным лучом покрытия оценивали не по изменению массы, а по глубине окисления $\mathrm{h}_{\mathrm{o}}$, а также по изменениям значений микротвердости и содержания алюминия. Полученная после лазерной обработки мелкодисперсная структура обладает высокой термической стабильностью и не претерпевает существенных изменений в ходе испытаний. Лишь на глубине $10-15$ мкм от поверхности (толщину этого приповерхностного слоя следует принимать за глубину окисления) происходит уменьшение содержания алюминия до $6-8$ мас. \%, что связано с расходованием этого элемента на образование защитной окисной пленки. При этом снижается значение микротвердости до $500 \mathrm{HV}$ 0,05.

В условиях жестких коррозионных испытаний в расплаве смеси солей 75 мас. \% $\mathrm{Na}_{2} \mathrm{SO}_{4}$ и 25 мас. \% $\mathrm{NaCl}$ при $900{ }^{\circ} \mathrm{C}$ лучшие защитные свойства показало комбинированное трехслойное покрытие без отжига в вакууме (рис. 16). После 50-часовых испытаний это покрытие полностью сохранилось на поверхности образцов. В покрытии, предварительно подвергнутом отжигу в вакууме, внешний керамический слой начинает растрескиваться и отслаиваться после 40 часов испытаний в расплаве солей. Очевидно, меньший запас алюминия в этом покрытии по сравнению с покрытием без предварительного отжига в вакууме приводит к более быстрому образованию шпинелей $\mathrm{NiAl}_{2} \mathrm{O}_{4}$ и $\mathrm{NiCr}_{2} \mathrm{O}_{4}$ на границе с керамическим слоем. Напряжения, возникающие при росте пленки этих соединений, способствуют растрескиванию внешнего керамического слоя $\left(\mathrm{ZrO}_{2}, \mathrm{Y}_{2} \mathrm{O}_{3}\right)$. 


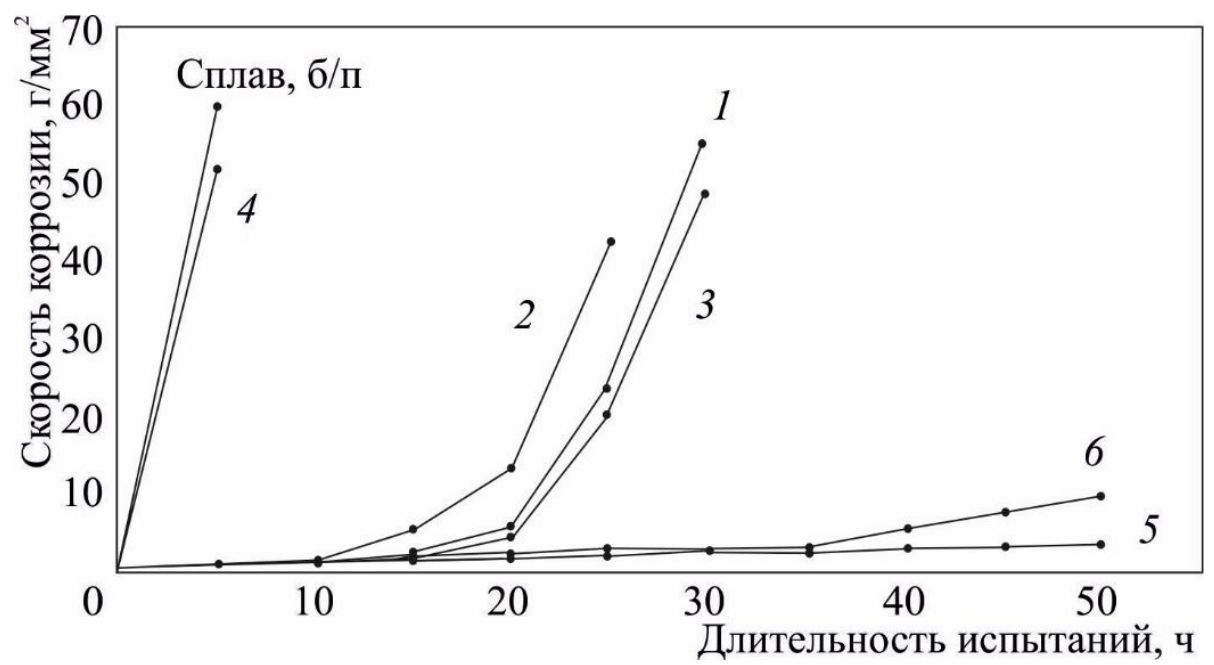

Рис. 16. Изменение средней скорости коррозии покрытий на сплаве ЭИ929:

1 - ДП + ПК; 2 - ДП + ПМ; 3 - ДП (приведено для сравнения); 4 - ПМ + ДП;

$5-$ ДП + ПМ + ПК; $6-$ ДП + ПМ + ПК + отжиг в вакууме $1050{ }^{\circ} \mathrm{C}$;

7 - без покрытия

Для покрытия ДП + ПК характерно следующее: после 20-часовой выдержки в расплаве солей происходит растрескивание и вспучивание керамического слоя, появляются зеленые наросты окислов $\mathrm{Cr}_{2} \mathrm{O}_{3}$ и $\mathrm{NiO}$. В дальнейшем покрытие уже не защищает сплав и коррозионные процессы определяются только свойствами основного металла.

Низкая коррозионная стойкость покрытия ДП + ПК связана с тем, что при толщине слоя алюминидов металлического покрытия 40-55 мкм запаса алюминия недостаточно для обеспечения образования защитного окисла $\mathrm{Al}_{2} \mathrm{O}_{3}$ в течение длительной выдержки в расплаве солей. Анализ поперечных шлифов показывает, что уже после 10-часовых коррозионных испытаний на некоторых участках поверхности образцов в ДП произошло $\beta \rightarrow \gamma^{\prime}$ превращение. В ходе дальнейших испытаний на этих участках вместо окисла $\mathrm{Al}_{2} \mathrm{O}_{3}$ образуется шпинель $\mathrm{NiAl}_{2} \mathrm{O}_{4}$ по границе с керамическим слоем, обладающая более низкими защитными свойствами в условиях солевой коррозии.

В условиях коррозионных испытаний в расплаве солей долговечность двухслойного покрытия ДП + ПМ не превышает 20 часов (см. рис. 16). Лазерная обработка такого покрытия привела к существенному повышению его коррозионной стойкости. После 50 часов испытаний не наблюдали отслоений и осыпания покрытия, проникновение продуктов коррозии вглубь оплавленного слоя отмечалось на глубине не более 50 мкм (см. табл. 7).

Таблица 7 - Глубина поврежденного слоя образцов с комбинированными покрытиями после 500 ч испытаний на жаростойкость $\left(\mathrm{h}_{\mathrm{o}}\right)$ и 50 ч коррозионных испытаний $\left(\mathrm{h}_{\kappa}\right)$

\begin{tabular}{|c|c|c|c|}
\hline № & Тип покрытия & $\mathrm{h}_{\mathrm{o}}$, мкм & $\mathrm{h}_{\text {к, мкм }}$ \\
\hline 1 & ДП + ПК & 0 & $300-380$ \\
\hline 2 & ДП + ПМ & $100-150$ & $300-380$ \\
\hline 3 & $\begin{array}{c}\text { ДП + ПМ + лазерная } \\
\text { обработка }\end{array}$ & $10-15$ & $50-60$ \\
\hline 4 & ДП + ПМ + ПК & $\begin{array}{c}\text { Единичные поры по границе ДП } \\
\text { и ПМ }\end{array}$ & $\begin{array}{c}\text { Локальные отслоения } \\
\text { по границе ДП и ПМ }\end{array}$ \\
\hline 5 & $\begin{array}{c}\text { ДП + ПМ + ПК + отжиг } \\
\text { в вакууме 10500С, 2 ч }\end{array}$ & $\begin{array}{c}\text { Единичные поры по границе ДП } \\
\text { и ПМ }\end{array}$ & $\begin{array}{c}\text { Локальные отслоения } \\
\text { по границе ДП и ПМ }\end{array}$ \\
\hline
\end{tabular}

Pugacheva N. B. / Current trends in the development of heat-resistant coatings based on iron, 
Таким образом, комбинированное покрытие, полученное при последовательном нанесении термодиффузионного слоя 28Al-2Si-1P3М, плазменного Ni-Cr-Al-Y и керамического $\left(\mathrm{ZrO}_{2}, \mathrm{Y}_{2} \mathrm{O}_{3}\right)$ слоев, обладает достаточно высокими защитными свойствами, особенно в условиях коррозионного воздействия сульфида и хлорида натрия. Дополнительный отжиг этого покрытия в вакууме при $1050{ }^{\circ} \mathrm{C}$ в течение 2 ч практически не влияет на жаро- и коррозионную стойкость. Для упрочнения наиболее опасных участков поверхности деталей, например входных кромок лопаток ГТД, можно применять лазерное оплавление комбинированного покрытия. При этом формируется однородная мелкодисперсная структура поверхностного слоя, которая может обеспечить высокую термическую стабильность и защитные свойства.

\section{4. Выводы}

Современные покрытия на основе алюминидов FeAl, NiAl и CoAl обладают достаточно высокими показателями жаро- и коррозионной стойкости. Исчерпание их защитных свойств связано, главным образом, с растрескиванием и выкрашиванием алюминидного слоя при эксплуатации. Поскольку зарождение трещин, как правило, происходит по межфазным границам между силицидами $\mathrm{M}_{5} \mathrm{Si}_{3}$ и $\beta$-фазой в случае диффузионных покрытий и между $\beta$-фазой и $\gamma$-твёрдым раствором для напыляемых покрытий, необходимо стремиться к формированию в покрытиях фаз с близкими значениями к.т.р., модуля нормальной упругости и близкими параметрами кристаллических решёток.

Общими недостатками как в диффузионных, так и в напыляемых покрытиях на основе алюминидов, ограничивающими их долговечность, являются склонность к выкрашиванию под действием скоростного газового потока и малая диффузионная стабильность в условиях эксплуатации. Учитывая вышесказанное, более перспективно использование комбинированных покрытий, получаемых последовательным нанесением нескольких слоёв разного химического и фазового состава, что позволяет недостатки одних слоёв уменьшать или сводить к нулю за счёт достоинств других.

\section{Литература}

1. Абраимов Н. В., Елисеев Ю. С. Химико-термическая обработка жаропрочных сталей и сплавов. - М. : Интермет Инжиниринг, 2001. - 622 с.

2. Goward G. W. Progress in coatings for gas turbine airfoils // Surface and Coatings Technology. - 1998. - No 108, 109. - P. 73-79.

3. Гузанов Б. Н., Косицын С. В., Пугачева Н. Б. Упрочняющие защитные покрытия в машиностроении. - Екатеринбург : УрО РАН, 2004. - 244 с.

4. Мовчан Б. А., Малашенко И. С. Жаростойкие покрытия, осаждаемые в вакууме. Киев : Наукова думка, 1983. - 232 с.

5. Сычёв М. М. Неорганические клеи. - Ленинград : Химия, 1986. - 152 с.

6. Свойства, получение и применение тугоплавких соединений: Справочник / под ред.

Т. Я. Косолаповой. - М. : Металлургия, 1986. - 928 с.

7. Влияние состава и структуры жаропрочных никелевых сплавов на строение и свойства диффузионных покрытий / С. В. Косицын, Н. Б. Вандышева, Б. Н. Гузанов и др. // Защитные покрытия на металлах. - Киев : Наукова думка, 1987. - Вып. 21. - С. 20-24.

8. Пугачева Н. Б., Косицын С. В., Бабич Н. В. Термодиффузионные покрытия на основе ферросплавов с РЗМ // Физика и химия обработки материалов. - 1998. - № 4. - С. 42-48.

9. Применение диффузионных покрытий для защиты высокохромистых никелевых сплавов от воздействия агрессивных газовых сред / В. Г. Сорокин, Б. Н. Гузанов, А. Н. Бабынькин, Н. Б. Вандышева и др. // в кн. : Температуроустойчивые покрытия. Ленинград : Наука, 1985. - С. 172-177.

10. Пугачева Н. Б., Экземплярова Е. О., Задворкин С. М. Исследование структуры и физических свойств сплавов Fe-Cr-Al // Металлы. - 2006. - № 1. - C. 68-75. 
11. Химико-термическая обрабока металлов и сплавов. Справочник / Г. В. Борисенок, Л. А. Васильев, Л. Г. Ворошнин и др. - М. : Металлургия, 1981. - 424 с.

12. Влияние кремния на диффузию в сплавах никель-алюминий / С. В. Косицын, В. С. Литвинов, В. Г. Сорокин, М. А. Гервасьев // Физика металлов и металловедение. - 1980. - Т. 49, № 5. - С. 1063-1067.

13. Исследование повреждаемости шликерных алюмосилипидных покрытий в процессе эксплуатации лопаток авиационных ГТД / Ю. Г. Смирнов, М. А. Лебедева, С. В. Косицын и др. // Авиационная промышленность. - 1988. - № 1. - С. 68-71.

14. Косицын С. В. Сплавы и покрытия на основе моноалюминида никеля. - Екатеринбург : Изд-во УрО РАН, 2008. - 278 с.

15. Мубояджан С. А., Лесников В. П., Кузнецов В. П. Комплексные защитные покрытия турбинных лопаток авиационных ГТД. - Екатеринбург : Изд-во «Квист», 2008. - 208 с.

16. Пугачева Н. Б. Мазаева Е. С. Защитные свойства высокотемпературных комбинированных покрытий // Физика и химия обработки материалов. - 2001. - № 4. - С. 82-90.

17. Многокомпонентные упрочняющие покрытия для высокотемпературных деталей мощных дизелей / Н. Б. Вандышева, П. А. Федоров, Н. В. Клюева и др. // Защитные покрытия на металлах. - 1990. - Вып. 24. - С. 100-104.

18. Padture N. P., Gell M., Jordan E. H. Thermal barrier coatings for gas-turbine engine applications // Science. - 2002. - Vol. 296. - P. 280-284.

19. Чубаров Д. А., Матвеев П. В. Новые керамические материалы для теплозащитных покрытий рабочих лопаток ГТД // Авиационные материалы и технологии. - 2013. - № 4. C. 43-46.

20. Разработка ионно-плазменных жаростойких металлических слоев теплозащитных покрытий для охлаждаемых рабочих лопаток турбин / С. А. Будиновский, С. А. Мубояджан, А. М. Гаямов, П. В. Матвеев // Металловедение и термическая обработка металлов. - 2013. № 12. - C. 16-21.

21. Failure modes in plasma-sprayed thermal barrier coatings / K. W. Schlichting, N. P. Padture, E. H. Jordan, M. Gell // Materials Science and Engineering. - 2003. - Vol. A342. - P. 120-130.

22. Zhu D., Miller R. A. Thermal Conductivity and Sintering Behavior of Advanced Thermal Barrier Coatings. NASA / TM-2002-211481. - 2002. - 15 p.

23. Выбор жаростойкого покрытия для жаропрочного никелевого рений-рутений содержащего сплава марки ВЖМ4 [Электронный ресурс] / А. М. Гаямов, С. А. Будиновский, С. А. Мубояджан, А. А. Косьмин // Труды «ВИАМ». - 2014. - № 1. - URL : http://viamworks.ru/plugins/content/journal/uploads/articles/pdf/639.pdf (дата обращения: 31.05.2015). 